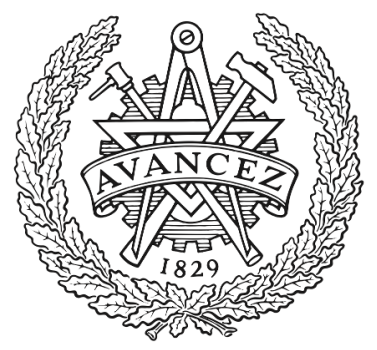

CHALMERS

UNIVERSITY OF TECHNOLOGY

\title{
Understanding the Interaction of Potassium Salts with an Ilmenite Oxygen Carrier under Dry and Wet Conditions
}

Downloaded from: https://research.chalmers.se, 2023-04-26 06:48 UTC

Citation for the original published paper (version of record):

Hildor, F., Zevenhoven, M., Brink, A. et al (2020). Understanding the Interaction of Potassium Salts with an Ilmenite Oxygen Carrier under Dry and

Wet Conditions. ACS Omega, 5(36): 22966-22977. http://dx.doi.org/10.1021/acsomega.0c02538

N.B. When citing this work, cite the original published paper. 


\title{
Understanding the Interaction of Potassium Salts with an IImenite Oxygen Carrier Under Dry and Wet Conditions
}

\author{
Fredrik Hildor,* Maria Zevenhoven, Anders Brink, Leena Hupa, and Henrik Leion
}

Cite This: ACS Omega 2020, 5, 22966-22977

Read Online

ABSTRACT: This study describes how potassium salts representative of those in bio ash affect the reactivity of the oxygen carrier ilmenite under moist and dry conditions. Ilmenite is a bench-mark oxygen carrier for chemical-looping combustion, a technique that can separate $\mathrm{CO}_{2}$ from flue gases with minimal energy penalty. Different potassium salts were mixed with ilmenite to a concentration of $4 \mathrm{wt} \%$ potassium. The salts used were $\mathrm{K}_{2} \mathrm{CO}_{3}$, $\mathrm{K}_{2} \mathrm{SO}_{4}, \mathrm{KCl}$, and $\mathrm{KH}_{2} \mathrm{PO}_{4}$. Experiments were performed at $850{ }^{\circ} \mathrm{C}$ under alternately oxidizing and reducing conditions in a dry atmosphere or in the presence of steam. Analyses of the oxygen carrier regarding changes in reactivity, structure, and composition followed the exposures. This study showed that salts such as

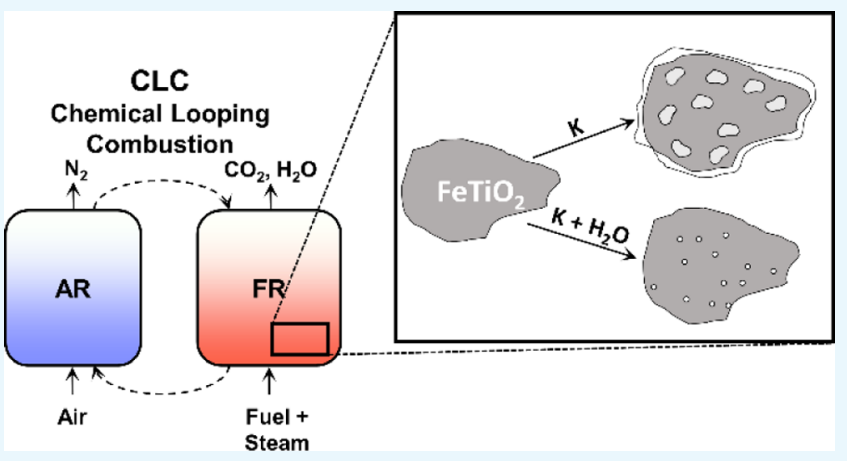
$\mathrm{K}_{2} \mathrm{CO}_{3}, \mathrm{~K}_{2} \mathrm{SO}_{4}$, and $\mathrm{KCl}$ increase the reactivity of the ilmenite. For the samples mixed with $\mathrm{KCl}$, most of the salt was evaporated. $\mathrm{KH}_{2} \mathrm{PO}_{4}$ decomposed into $\mathrm{KPO}_{3}$, forming layers around the ilmenite particles that lead to agglomeration. Additionally, the $\mathrm{KPO}_{3}$ layer was more or less nonpermeable for $\mathrm{CO}$ and decreased the reactivity toward $\mathrm{H}_{2}$ significantly in both dry and wet conditions. This decreased reactivity indicates that the concentration of phosphorus in biofuel may have a significant effect on oxygen carrier degradation. It was also observed that the presence of steam changed the chemistry drastically for the nonphosphorus-containing salts. Alkali salts may react with steam, forming volatile $\mathrm{KOH}$ that evaporates partly. $\mathrm{KOH}$ may also form K-titanates by reaction with the oxygen carrier, leading to segregation of iron and titanium phases in the ilmenite.

\section{INTRODUCTION AND BACKGROUND}

The Paris Agreement aims to strengthen the global response toward the threats of climate change, stating goals such as remaining "well below $2{ }^{\circ} \mathrm{C}$ " and "pursuing efforts to limit the temperature increase to $1.5{ }^{\circ} \mathrm{C}$ ", compared to preindustrial temperatures. ${ }^{1}$ In order to achieve these goals, increased energy efficiency and development toward a carbon-neutral society is essential. In addition, $\mathrm{CO}_{2}$ might also be needed to be extracted from the atmosphere. ${ }^{2}$ Using technologies such as carbon capture and storage (CCS), anthropogenic $\mathrm{CO}_{2}$ emissions can be reduced to zero or even become negative. A possibility to achieve negative emissions is the capturing of $\mathrm{CO}_{2}$ from the combustion of biomass fuels, so-called BECCS-bioenergy with carbon capture and storage (BECCS). Negative emissions might have significant technical and economic importance in the future in order to obtain a global $\mathrm{CO}_{2}$ concentration in the atmosphere at a sustainable level.

Combustion techniques using oxygen carriers such as chemical looping combustion (CLC) may be excellent choices for CCS or BECCS. In CLC, a solid oxygen carrier is used instead of air to provide oxygen to the fuel. The fundamental principle of CLC and similar techniques using oxygen carriers is shown in Figure 1. The fuel is oxidized using two separate reactor vessels, the air reactor (AR) and the fuel reactor (FR). A
CLC

Chemical Looping Combustion

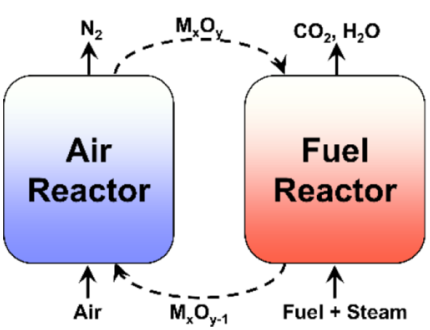

OCAC

Oxygen Carrier Aided Combustion

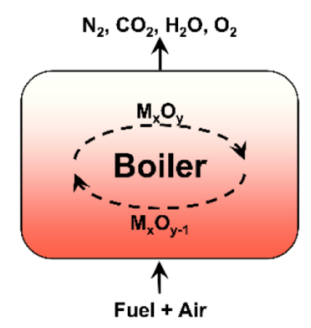

Figure 1. Principle of CLC and oxygen carrier-aided combustion (OCAC), two examples of techniques where oxygen carriers like ilmenite can be used.

Received: May 29, 2020

Accepted: August 19, 2020

Published: September 2, 2020

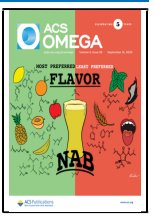


solid oxygen carrier in the form of metal oxide particles $\left(\mathrm{M}_{x} \mathrm{O}_{y}\right)$ transports oxygen between the two reactors. In the FR, the fuel reacts with oxygen provided by the oxygen carrier particles and $\mathrm{CO}_{2}$ and $\mathrm{H}_{2} \mathrm{O}$ are produced. In the $\mathrm{AR}$, the oxygen carrier is regenerated with $\mathrm{O}_{2}$ from the air. To maintain the process, the oxygen carrier needs to be functional and not degraded by physical stress or chemical reactions.

Compared to coal, biomass has a lower energy density, a greater variety in composition, and a significantly different ash composition. $^{4,5}$ Generally, biomass fuels have substantial amounts of the elements: $\mathrm{Ca}, \mathrm{K}, \mathrm{S}, \mathrm{P}, \mathrm{Cl}, \mathrm{Mg}$, and $\mathrm{Si}$ that end up in the ash. ${ }^{5}$ Especially, alkali compounds are known to contribute to agglomeration in fluidized bed combustion, ${ }^{4,6}$ whereas $\mathrm{K}$ and $\mathrm{Cl}$ may contribute to corrosion of boilers as well. ${ }^{4}$ Ash compounds may also interact with oxygen carriers used in chemical looping applications. They may either inhibit or catalyze combustion reactions taking place and contribute to an agglomeration of the bed. Therefore, it is essential to investigate and find potential oxygen carriers that can operate under diverse fuel conditions both from a technical, economic, and sustainable point of view. ${ }^{7-9}$

Conversion techniques using oxygen carriers, such as CLC or OCAC, for biomass conversion usually use low-cost oxygen carriers. These oxygen carriers can be materials such as ores, slags, or particles with active components such as iron or manganese. ${ }^{10-13}$ An ore that has been investigated as an oxygen carrier more deeply is ilmenite, whose main component is $\mathrm{FeTiO}_{3}{ }^{9,14-16}$ Because it is so well studied, it can be considered as a benchmark oxygen carrier and has therefore been used as a model oxygen carrier for large-scale CLC. ${ }^{17}$ Based on the iron content of ilmenite, the reduction capacity is theoretically limited to $5 \mathrm{wt} \%$. The reduction can be described by reaction 1 , where the oxidized phase is called pseudobrookite and the reduced phase is called ilmenite.

$$
\mathrm{Fe}_{2} \mathrm{O}_{3} \cdot \mathrm{TiO}_{2}(\mathrm{~s})+\mathrm{TiO}_{2}(\mathrm{~s})+\mathrm{CO}(\mathrm{g}) \stackrel{\mathrm{red}}{\longrightarrow} 2 \mathrm{FeO} \cdot \mathrm{TiO}_{2}(\mathrm{~s})+\mathrm{CO}_{2}(\mathrm{~g})
$$

Ilmenite, as an oxygen carrier, has been investigated in both CLC pilot plants and conventional power plants operated under OCAC conditions. These studies showed that Fe migrates toward the surface of the OC and potassium from the ash migrates to the center of the OC particles where it interacts with titanium and forms K-titanates. ${ }^{18-21}$ This segregation is also known as alkali roasting within the titanium dioxide industry, where sodium hydroxide and potassium carbonate are utilized to increase the separation rate between iron and titanium. During alkali roasting, the alkali metal reacts with iron and titanium in the ilmenite that separates the combined phase into two different phases: alkali-iron oxide and alkali-titanium oxide. This phase separation is needed to obtain pig iron and the titanium oxide in the Becher process. ${ }^{22-27}$ Alkali impregnation on ilmenite has also been indicated to increase the reaction rate of the oxygen carrier in chemical looping applications. ${ }^{28,29}$ However, as have been observed in a $100 \mathrm{~kW}$ CLC reactor with a mixture of ilmenite and manganese ore, a share of alkali is evaporated and found in both the FR and AR when operated under CLC. ${ }^{30}$ Nevertheless, it is unknown how different ash components interact with ilmenite during CLC operation under moist and dry conditions. Understanding these interactions is of utmost interest because inhibition of oxygen carrier reactivity, agglomeration, and alkali evaporation with resulting corrosion may occur when combusting certain kinds of biomass.

Zevenhoven et al. (2018) studied the agglomeration tendency of ilmenite ore in the presence of potassium salts under dry oxidizing conditions. It revealed the interaction of these salts with the bed material leading to molten or sintered phases and possible defluidization of the ilmenite bed material in the presence of $\mathrm{K}_{2} \mathrm{CO}_{3}$ and $\mathrm{KH}_{2} \mathrm{PO}_{4}$, respectively. ${ }^{19}$ Scarce literature is available on more fundamental studies on the interaction of ash compounds with ilmenite under reducing conditions with the presence of steam.

The work presented here is a fundamental study focusing on the reactivity and properties of ilmenite ore in the presence of different potassium salts under reducing and oxidative conditions. The reduction and oxidation are intended to mimic the phase changes of the oxygen carrier that occurs in CLC and other chemical looping applications. Both a dry and wet atmosphere was used to investigate the importance of steam for further interaction studies. Potassium salts were used because potassium is the most common alkali metal in biomass, ${ }^{4}$ and sodium and potassium are considered to be interconvertible regarding alkali roasting of ilmenite at temperatures below 860 ${ }^{\circ} \mathrm{C}{ }^{24,25}$ Potassium in biomass ash is present as carbonates, sulfates, chlorides, and phosphates. ${ }^{4,31}$ Therefore, these potassium salts have been used in this study.

\section{EXPERIMENTAL SECTION}

2.1. Materials Used. The oxygen carrier used was Norwegian rock ilmenite provided by Titania $\mathrm{AB}$. The same material has been characterized and used for experiments in previous studies. ${ }^{9,18,19,32}$ The ilmenite ore contained 94.3 wt \% Fe and $\mathrm{Ti}$ oxides and it had a size range of $100-300 \mu \mathrm{m}$. The $\mathrm{Fe}-\mathrm{Ti}$ ratio is determined to be roughly 1.07. The impurities in the ore were mostly $\mathrm{Si}, \mathrm{Mn}$, and $\mathrm{Mg}$. ${ }^{9}$ The ilmenite was heattreated at $950{ }^{\circ} \mathrm{C}$ for $6 \mathrm{~h}$ in a muffle furnace to fully oxidize the material, as suggested by Adánez et al. ${ }^{33}$ It was this heat-treated ilmenite that was used in the following experiments.

The potassium salts $\mathrm{K}_{2} \mathrm{CO}_{3}, \mathrm{~K}_{2} \mathrm{SO}_{4}, \mathrm{KCl}$, and $\mathrm{KH}_{2} \mathrm{PO}_{4}$ used for the experiments were of high purity grade $(>99 \%)$ and were grounded in a mortar before use. Four samples of ilmenite particles were mixed with the respective grounded potassium salt so that the final samples contained 4 wt $\%$ potassium. This value was chosen because $4 \mathrm{wt} \%$ potassium was the amount of accumulated potassium found in the bed after three weeks of operation in a semi-industrial biomass CFB boiler operated with ilmenite under OCAC conditions. ${ }^{18}$ Important to notice is that this resulted in that different amounts of salts were used for the different samples to obtain 4 wt $\%$ potassium.

2.2. TGA Analyses of Mixtures of IImenite Ore with Potassium Salts. A pressurized thermogravimetric analyzer (TGA) was used in the atmospheric mode to investigate the reactivity of the ilmenite and ilmenite-salt mixtures in a dry and moist atmosphere, respectively. To avoid corrosion of the TGA, samples containing $\mathrm{KCl}$ were omitted from TGA experiments. However, $\mathrm{KCl}$ was used in all other experiments in this work.

$100 \mathrm{mg}$ samples were exposed to atmospheres that mimicked the CLC process, that is, cycles of reducing and oxidizing atmospheres. Heating from room temperature up was performed under inert conditions with $\mathrm{N}_{2}$ with a ramp of 15 ${ }^{\circ} \mathrm{C} / \mathrm{min}$. At an operating temperature of $850{ }^{\circ} \mathrm{C}$, a $900 \mathrm{~s}$ 
stabilization period was performed under inert conditions before reductive gases were introduced into the TGA. For experiments under moist conditions, the reduction was carried out in 5\% CO or $\mathrm{H}_{2}$ and $50 \%$ steam in $\mathrm{N}_{2}$, followed by flushing with $\mathrm{N}_{2}$. Experiments in dry conditions were carried out with similar gas flows with additional $\mathrm{N}_{2}$ instead of steam. Hereafter, the oxidation took place in $20 \% \mathrm{O}_{2}$ and $50 \%$ steam in $\mathrm{N}_{2}$ for wet experiments and with only $\mathrm{N}_{2}$ for dry experiments. The total flow rate was $1000 \mathrm{~mL}_{\mathrm{N}} / \mathrm{min}$ followed by flushing. Hereafter, the cycle was repeated. Steam was generated by boiling a small flow of liquid water. Because of experimental limitations, $\mathrm{H}_{2} \mathrm{O}$ was also generated during the oxidation. This has no real application into the chemical lopping processes because the AR is fluidized with air. However, this should not have any greater effect on the oxidation level of oxidized ilmenite because steam is not affecting the pseudobrookite phase.

The reduction time was set to $60 \mathrm{~min}$, that is, long enough for a control ilmenite sample to reach a weight loss caused by the reduction of $3 \mathrm{wt} \%$ in CO. $3 \mathrm{wt} \%$ was considered as the worst case based on the $1000 \mathrm{MW}_{\text {th }}$ design of an ilmenite CLC plant with an expected reduction rate of $1.5 \mathrm{wt} \% .{ }^{17}$ Also, for other applications such as chemical looping gasification, further reduction is essential to limit the oxygen transport in the $\mathrm{FR}^{34}$ The oxidation time was set to $30 \mathrm{~min}$, that is, the time required to regain the original weight of a pure ilmenite sample. To compensate for buoyancy effects in the equipment, reference samples with silicon oxide were treated similarly as the samples containing ilmenite and salts and the results were used for the correction. Mean values collected every $40 \mathrm{~s}$ were used to smooth fluctuations from the steam generator.

2.3. Interaction of Potassium Salts with IImenite in a Tubular Furnace. The sample amount used in the TGA is only $100 \mathrm{mg}$; these samples were too small to be characterized with $\mathrm{X}$-ray diffraction (XRD). Therefore, experiments were carried out in a tubular furnace, where $1 \mathrm{~g}$ sample was placed in an alumina crucible and treated in a reducing atmosphere containing $5 \% \mathrm{CO}$ at $850{ }^{\circ} \mathrm{C}$ for $6 \mathrm{~h}$, both in a dry atmosphere and with 50\% steam. In all experiments, a total gas flow of 1000 $\mathrm{mL}_{\mathrm{N}} / \mathrm{min}$ was maintained. The steam was produced in a preheater before the furnace. Here, the water was evaporated at $200{ }^{\circ} \mathrm{C}$. Water to the preheater was supplied by a peristaltic pump. The setup of the experiments using the tubular furnace is shown in Figure 2.35 Thermocouples placed near the sample registered the temperature in the furnace.

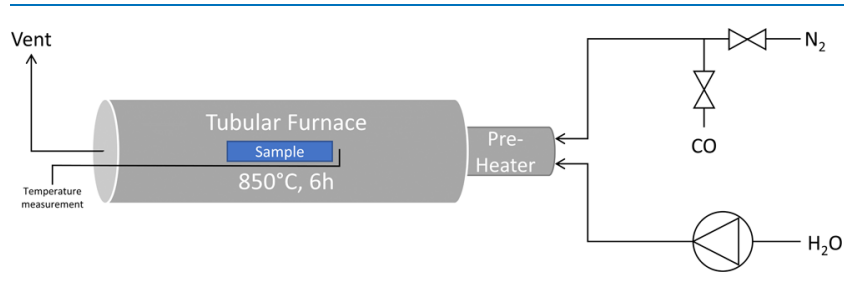

Figure 2. Setup for the tubular furnace where a $1 \mathrm{~g}$ sample was mounted in the center of the furnace in an alumina crucible.

2.4. SEM/EDS and XRD Analysis. Particles from the experiments were studied using a scanning electron microscope coupled with an energy-dispersive X-ray analyzer (SEM/EDS). The microscope used was a LEO Gemini 1530 with a Thermo Scientific UltraDry silicon drift detector. The particles were counted on carbon tape and the surface studied.
The cross section of the samples was analyzed by mounting the samples in epoxy resin. Then, the samples were polished until a cross section was visible for SEM/EDS analyses. The surface was carbon-sputtered to increase conductivity. For each sample, elemental maps facilitate the determination of the elemental distribution over the analyzed cross section. A similar investigation of the byproducts steel converter slag and mill scale has been performed in the same equipment. ${ }^{35}$

XRD analyses of the samples were carried out using a Bruker AXS D8 Discover instrument (Karlsruhe, Germany). The data were collected between 20 and $80^{\circ} 2 \theta$; using a step size of $0.05^{\circ}$. The X-ray tube was operated at $40 \mathrm{kV}$ and $40 \mathrm{~mA}$.

2.5. Global Equilibrium Analyses: Factsage 7. Thermodynamic calculations were made to predict the stable equilibrium phases at the experimental conditions in the laboratory tests. The calculations were performed with the thermodynamic software Factsage, version 7.0. ${ }^{36}$

The thermodynamic data for the calculations were taken from the databases: FactPS for pure substances, FToxid for oxide phases, and FTsalt for molten salts. All calculations were performed at a temperature of $850^{\circ} \mathrm{C}$ at a total pressure of 1 bar. The input values for the carrier material and salt mixtures were a total of $1 \mathrm{~g}$ mixture. The amount of the gas mixture was one mol of the experimental atmospheres.

\section{RESULTS AND DISCUSSION}

3.1. TGA Studies. Results from the different TGA test conditions are shown in Figures 3 and 4. In all tests, the weight

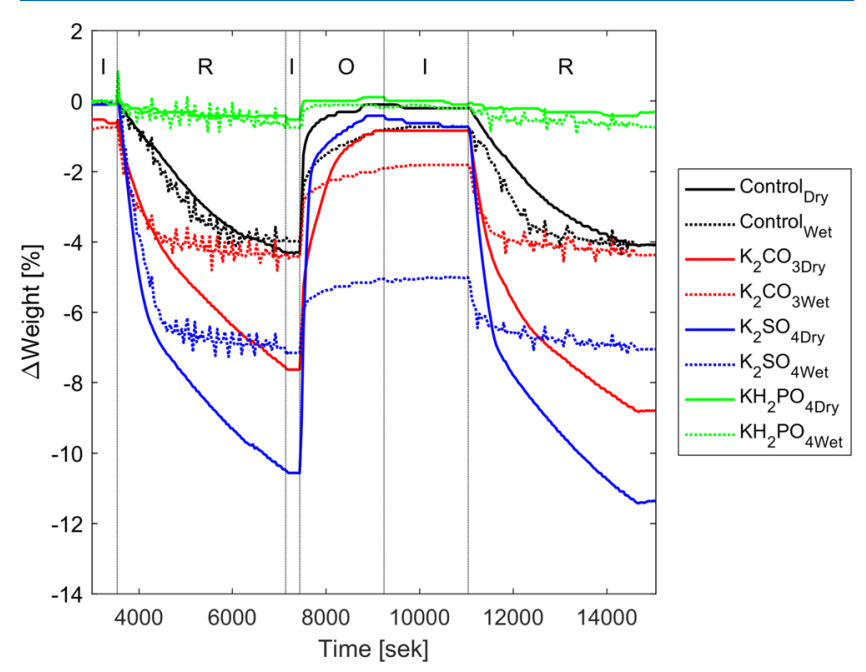

Figure 3. TGA results from samples reduced with $5 \% \mathrm{CO}$. The atmospheric conditions over time are marked in the top of the figure divided into segments: "I": inert, "R": reducing with $\mathrm{CO}$, with or without steam, "O": oxidizing conditions.

gain of the samples during oxidation was faster than the weight loss in the reduction. This was not surprising when considering the difference in $\mathrm{O}_{2}$ present in the atmosphere, that is, 20 versus $5 \%$ besides the higher kinetics for the oxidation reaction. Similar to previous studies with other iron-based oxygen carriers and ilmenite, potassium increases the reaction rate of the reduction. ${ }^{23,37}$

3.1.1. Tests in $\mathrm{CO}$. The results from the reduction cycles using $\mathrm{CO}$ in the TGA are displayed in Figure 3. The initial reduction of pure ilmenite seemed to be faster when steam was added to the 


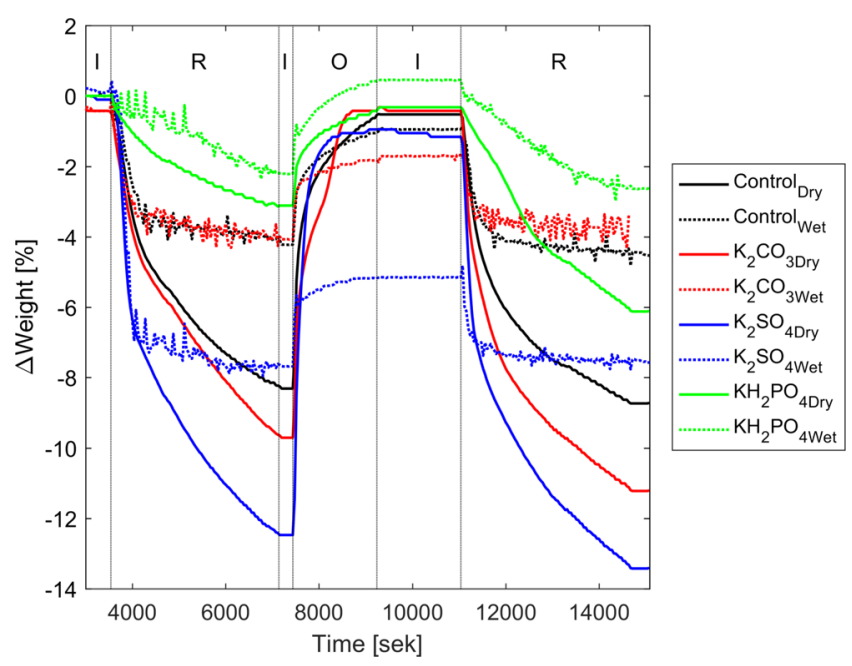

Figure 4. TGA results from samples reduced with $5 \% \mathrm{H}_{2}$. The atmospheric conditions over time are marked in the top of the figure divided into segments: "I": inert, "R": reducing with $\mathrm{H}_{2}$, with or without steam, "O": oxidizing conditions.

atmosphere. The total reduction ended at around $4 \%$ weight loss in both cases.

In the ilmenite $-\mathrm{K}_{2} \mathrm{CO}_{3}$ mixture, $\mathrm{K}_{2} \mathrm{CO}_{3}$ is believed to react with the ilmenite forming $\mathrm{K}$-titanates releasing $\mathrm{CO}_{2}$ under dry conditions. The weight loss after reduction was far smaller in the test runs containing steam, that is, $4 \%$ mass loss compared to $\sim 8 \%$. In the wet test, the initial mass loss rate was larger when compared to the reduction of pure ilmenite but both ended at the same mass loss level of some $4 \%$. It is important to notice that samples in these conditions both decrease in weight because of loss of oxygen and salts. Under dry conditions, it is possible to reduce the pseudobrookite structure more than to the ilmenite structure, that is, it is possible to over reduce the samples forming an elementary iron. In relation to the theoretical mass reduction of pseudobrookite, a 5\% mass reduction of oxygen should correspond to ilmenite and 15\% mass reduction correspond to the formation of elementary iron and titanium dioxide.

The reduction of the ilmenite $-\mathrm{KH}_{2} \mathrm{PO}_{4}$ mixture showed no major difference in reduction in either dry or moist atmosphere. The $\mathrm{KH}_{2} \mathrm{PO}_{4}$ formed $\mathrm{KPO}_{3}$, and this inhibited the reduction in both cases. $\mathrm{KPO}_{3}$ was indicated both using XRD and from the detected weight loss during the heating, roughly $1.6 \mathrm{wt} \%$ where the theoretical weight reduction was $1.9 \mathrm{wt} \%$. The conversion of $\mathrm{KH}_{2} \mathrm{PO}_{4}$ to $\mathrm{KPO}_{3}$ occurring during the heating is not shown in Figure 3 but can be found in the Supporting Information. This result indicates that the presence of phosphorus may lead to the premature degradation of the oxygen carrier. Probably, the layer of phosphorus compounds from fuel ash may not have the same impervious property as $\mathrm{KH}_{2} \mathrm{PO}_{4}$ and a smaller effect of the total degradation of the oxygen carrier may be expected than encountered in the tests described above. Other compounds that form a layer around the particle, such as calcium compounds, ${ }^{18}$ or the presence of mechanical and chemical stresses will break down the particles, as seen by Knutson and Linderholm, ${ }^{9}$ which could reduce the effect of the phosphorus layer. In a similar study with an oxygen carrier containing calcium, the blocking of oxygen transport was much less compared to this study. ${ }^{35}$

Under dry circumstances, the mass loss of the ilmenite $\mathrm{K}_{2} \mathrm{SO}_{4}$ mixture was $\sim 11 \%$, whereas the mass loss was only $\sim 8 \%$ for the ilmenite mixtures in wet conditions, indicating the release of different sulfur compounds from the sample beside the loss of oxygen caused by reduction of ilmenite. The wet run shows that the mixture did not regain its original weight during oxidation. This is because of the sulfur compounds released from the mixture during the first reduction. This loss of sulfur is also the reason why the first reduction reaction for the $\mathrm{K}_{2} \mathrm{SO}_{4}$ sample is so much faster than the other sample containing potassium. After the first reduction and oxidation, the sulfur is removed in the sample resulting in that the rate of the second reduction is roughly the same for the wet $\mathrm{K}_{2} \mathrm{SO}_{4}$ and $\mathrm{K}_{2} \mathrm{CO}_{3}$ samples.

3.1.2. Tests in $\mathrm{H}_{2}$. TGA results for samples reduced with $\mathrm{H}_{2}$ in both dry and wet atmosphere are shown in Figure 4. When considering dry conditions, the test results show that $\mathrm{H}_{2}$ reduced all samples faster than $\mathrm{CO}$, the same results that have been obtained in previous studies. ${ }^{38}$ The second reduction showed a faster reaction rate when comparing the two different atmospheres.

The reduction of pure ilmenite was faster when using $\mathrm{H}_{2}$ in a dry atmosphere and the mass loss was larger when compared to the experiments using $\mathrm{CO}$. The mass loss after the first reduction was $8 \%$, far larger than expected. This indicates the reduction to elementary iron, also indicated in SEM/EDS. In wet conditions, the mass loss was some $4 \%$, that is, comparable to experiments using CO. At this reduction level, it is most likely that the ilmenite phase is present and further reduction is limited because of steam. After the first reduction, ilmenite was oxidized and gained its original weight back. The second reduction was comparable to the first one.

Under dry conditions, the first reduction of the ilmenite$\mathrm{K}_{2} \mathrm{CO}_{3}$ mixture yielded a greater mass loss compared to the mass loss in tests with pure ilmenite, that is, almost $10 \%$. Under wet conditions, the mass loss curves are comparable to the results obtained from pure ilmenite and the runs using wet $\mathrm{CO}$.

After the first reduction, the mass loss for the ilmenite $-\mathrm{K}_{2} \mathrm{SO}_{4}$ mixture was almost $12 \%$ in dry conditions. Hereafter, the mixture was re-oxidized but did not reach its original mass. $\sim 1 \%$ of the sample was lost. The second reduction was similar to the first one.

The mass loss curves look different for the experiment carried out in wet conditions. Mass loss after the first reduction was only $\sim 8 \%$. The sample does not regain weight to its original but some $5 \%$ remained lost, indicating the release of sulfur compounds. The mass loss after the second reduction was much smaller, that is, $\sim 3 \%$ was lost after the oxidation step, indicating a reduction of probably pure ilmenite.

In the sample mixtures where $\mathrm{K}_{2} \mathrm{SO}_{4}$ was present, the mass loss was greater in both the investigated atmospheres compared to the other salts. This mass loss could be contributed to the loss of $\mathrm{S}$ from the sample either as $\mathrm{SO}_{2}$ or as $\mathrm{H}_{2} \mathrm{~S}$. Some volatile $\mathrm{KOH}$ may have formed as well. However, neither the amount of $\mathrm{KOH}$ formed nor sulfur species could not be quantified. To determine potassium loss to flue gas, analysis of $\mathrm{KOH}$ in gas or elemental analysis of remaining oxygen carrier would be needed. However, the sample volumes were too small for this. The formation of volatile $\mathrm{S}$ species and $\mathrm{KOH}$ was also predicted from the global equilibrium analyses.

3.1.3. Comparison of Test Atmosphere. Test runs with CO and steam give similar results when compared to experiments with $\mathrm{H}_{2}$ and steam. The $\mathrm{CO}$ shift reaction facilitates the formation of $\mathrm{CO}_{2}$ and $\mathrm{H}_{2}$. Thus, these gases may be present in the gas mixture as well. An exception is a test with pure ilmenite. 
As in previous studies, in the $\mathrm{CO}$ atmosphere, ilmenite was slowly reduced than in $\mathrm{H}_{2}$. ${ }^{38}$

The initial mass loss of the samples was almost linear for samples containing pure ilmenite, ilmenite- $\mathrm{K}_{2} \mathrm{SO}_{4}$, and ilmenite $-\mathrm{K}_{2} \mathrm{CO}_{3}$, both $\mathrm{CO}$ and $\mathrm{H}_{2}$. At $4000 \mathrm{~s}$ in Figures 4 and 3, a slower rate appeared. This "breakpoint" could correspond to the formation of Fe from ilmenite. Comparing the weight reduction between the same samples reduced, with or without steam, it can be concluded that the speed of weight reduction is more or less the same if steam is present or not. However, comparing the first reduction cycle with the second reduction, for the same material, it can be concluded that the reaction rate increased in the second cycle. The increased reactivity is probably related to the segregation of iron and titanium. $^{33}$

In dry tests, it can be seen that the presence of $\mathrm{K}_{2} \mathrm{CO}_{3}$ increased the mass loss rate of the ilmenite mixtures. This increased reaction rate was expected because $\mathrm{K}_{2} \mathrm{CO}_{3}$ can be used as an element to increase the reduction rate in alkali roasting of ilmenite ore for titanium dioxide production. ${ }^{24}$

For samples with $\mathrm{KH}_{2} \mathrm{PO}_{4}$, the formation of a $\mathrm{KPO}_{3}$ layer resulted in a reduced reactivity toward the $\mathrm{CO}$ and $\mathrm{H}_{2}$. However, although $\mathrm{KPO}_{3}$ could block the reduction of ilmenite by $\mathrm{CO}$ more or less completely, this blockage was not seen to the same extent using $\mathrm{H}_{2}$. Apparently, the smaller nonpolar $\mathrm{H}_{2}$ molecules could penetrate the phosphate layer formed on the ilmenite.

3.2. Reaction Products. 3.2.1. XRD Analyses: Identification of Reaction Products after the First Reduction Step. XRD analysis was performed on all samples reduced in the tubular furnace. These XRD results are displayed in Table 1 .

Table 1. Results from the XRD Analyses of the Samples Reduced in $\mathrm{CO}$ at $850^{\circ} \mathrm{C}$ during $6 \mathrm{~h}$ in the Tubular Furnace ${ }^{a}$

\begin{tabular}{|c|c|c|c|c|}
\hline \multirow{2}{*}{$\begin{array}{c}\begin{array}{c}\text { gas } \\
\text { conditions }\end{array} \\
\text { sample }\end{array}$} & \multicolumn{2}{|c|}{ without steam } & \multicolumn{2}{|c|}{ with steam } \\
\hline & $\begin{array}{l}\text { iron and } \\
\text { titanium phases }\end{array}$ & $\begin{array}{l}\text { potassium } \\
\text { phases }\end{array}$ & $\begin{array}{l}\text { iron and titanium } \\
\text { phases }\end{array}$ & $\begin{array}{l}\text { potassium } \\
\text { phases }\end{array}$ \\
\hline $\begin{array}{l}\text { pure } \\
\text { ilmenite }\end{array}$ & $\begin{array}{l}\mathrm{Fe}, \mathrm{Fe}_{2} \mathrm{O}_{3} \\
\mathrm{FeO} \cdot \mathrm{TiO}_{2} \\
\mathrm{TiO}_{2}\end{array}$ & no salt & $\begin{array}{l}\mathrm{FeO} \cdot \mathrm{TiO}_{2} \\
\mathrm{Fe}_{2} \mathrm{O}_{3}\end{array}$ & no salt \\
\hline $\mathrm{K}_{2} \mathrm{CO}_{3}$ & $\begin{array}{l}\mathrm{Fe}, \mathrm{FeO} \cdot \mathrm{TiO}_{2} \\
\mathrm{TiO}_{2}\end{array}$ & K-titanate & $\begin{array}{l}\mathrm{FeO} \cdot \mathrm{TiO}_{2} \\
\quad(\mathrm{FeO})_{2} \cdot \mathrm{TiO}_{2}\end{array}$ & K-titanate \\
\hline $\mathrm{KCl}$ & $\begin{array}{l}\mathrm{Fe}, \mathrm{FeO} \cdot \mathrm{TiO}_{2} \\
(\mathrm{FeO})_{2} \cdot \mathrm{TiO}_{2} \\
\mathrm{TiO}_{2}\end{array}$ & $\begin{array}{c}\text { no } \mathrm{K} \text { or } \mathrm{Cl} \\
\text { detected }\end{array}$ & $\begin{array}{l}\mathrm{FeO} \cdot \mathrm{TiO}_{2} \\
\mathrm{Fe}_{2} \mathrm{O}_{3}\end{array}$ & K-titanate \\
\hline $\mathrm{K}_{2} \mathrm{SO}_{4}$ & $\mathrm{Fe}, \mathrm{TiO}_{2}$ & $\begin{array}{l}\mathrm{FeS}, \\
\text { K-titanate }\end{array}$ & $\mathrm{FeO} \cdot \mathrm{TiO}_{2}, \mathrm{Fe}_{x} \mathrm{O}_{y}$ & K-titanate \\
\hline $\mathrm{KH}_{2} \mathrm{PO}_{4}$ & $\begin{array}{l}\mathrm{Fe}_{2} \mathrm{O}_{3} \cdot \mathrm{TiO}_{2} \\
\mathrm{TiO}_{2}\end{array}$ & $\begin{array}{l}\mathrm{KPO}_{3} \\
\mathrm{P}_{2} \mathrm{O}_{5}\end{array}$ & $\begin{array}{l}\mathrm{FeO} \cdot \mathrm{TiO}_{2} \\
\mathrm{Fe}_{2} \mathrm{O}_{3}, \mathrm{TiO}_{2} \\
\mathrm{Fe}_{2} \mathrm{O}_{3} \cdot \mathrm{TiO}_{2}\end{array}$ & $\begin{array}{l}\mathrm{KPO}_{3} \\
\mathrm{P}_{2} \mathrm{O}_{5}\end{array}$ \\
\hline
\end{tabular}

${ }^{a}$ The results from the analysis are divided into two different groups: (i) phases that contain only iron and titanium and (ii) potassiumcontaining phases resulted from the interaction and reactions of the potassium salts.

Unfortunately, the intense background noise prohibited any closer analysis of trace elements and only the major components were identified. The results presented in Table 1 indicate that several different phases of K-titanates might be present in a sample. Most likely, the samples contained a mixture of different K-titanate phases. In Table 1, only the best fitting compound is presented. Also, because ores were used with content of impurities, no quantitative analysis could be performed to estimate the elementary iron generated during the reduction.
Comparing the TGA results in Figures 3 and 4 and the XRD results in Table 1, they confirm the formation of $\mathrm{CO}_{2}$ from the ilmenite $-\mathrm{K}_{2} \mathrm{CO}_{3}$ mixture and loss of carbonate when $\mathrm{K}$-titanate is formed.

In the ilmenite $-\mathrm{K}_{2} \mathrm{SO}_{4}$ mixture treated with steam, hydrated potassium titanate was found. However, hydrated titanates are not stable at high temperatures. It is postulated here that its formation occurred during the cooldown in the presence of condensed steam.

XRD results confirmed the formation of $\mathrm{KPO}_{3}$, which was indicated from the weight reduction in TGA during the heating of the ilmenite- $\mathrm{KH}_{2} \mathrm{PO}_{4}$ mixture.

3.2.2. Thermodynamics Equilibrium Calculations. Table 2 describes the findings of the thermodynamic equilibrium calculations. Here, some similarities could be seen from the $\mathrm{XRD}$ results in Table 1 . Without steam, the reduction results in elementary iron and with steam, there is a thermodynamic limitation at ilmenite and ulvospinel $(\mathrm{FeO})_{2} \mathrm{TiO}_{2}$. With steam, it was also expected to form $\mathrm{KOH}$ in the gas phase for all reduced samples and also $\mathrm{KCl}$ and $\mathrm{HCl}$ in gas for the $\mathrm{KCl}$ sample.

A major difference between the calculated phases and the detected phases with XRD was for the $\mathrm{KH}_{2} \mathrm{PO}_{4}$ samples. Indicated from the TGA and detected with XRD was the $\mathrm{KPO}_{3}$ phase. This indicates that the thermodynamic database or conditions were not suitable for this mixture.

3.2.3. SEM/EDS Analyses. SEM/EDS analyses were performed on both the samples retrieved from the tubular furnace (once reduced in $\mathrm{CO}$, with and without moisture) as from the TGA experiments (twice reduced in either $\mathrm{CO}$ or $\mathrm{H}_{2}$ with or without moisture). Samples from the tubular furnace were reduced only once compared to the TGA samples that were reduced twice with an intermediate oxidation. The SEM/ EDS analyses showed similar elemental distribution comparing tubular and TGA samples. SEM/EDS analysis of the tubular samples can be found in the Supporting Information.

3.2.4. Heat Treatment of the IImenite. In accordance with Adánez et al. ${ }^{33}$ and other studies of the same material, ${ }^{9,19}$ XRD and SEM/EDS analyses of the fresh ilmenite showed that the sample contained mainly ilmenite $\left(\mathrm{FeO} \cdot \mathrm{TiO}_{2}\right)$ and some magnesium silicate $\left(\mathrm{MgSiO}_{3}\right)$. After the heat treatment, that is, oxidation of the particles at $950{ }^{\circ} \mathrm{C}$ for $6 \mathrm{~h}$, some structural changes in and at the surface of the particles could be observed. Internally, more small cracks crossed the otherwise still homogenous particles. Meanwhile, towards the surface of the particle, segregation of iron was observed, see Figure 5. The appearance of the particles obtained in this study, both fresh and pretreated, was in this respect similar to previous studies. ${ }^{19,33}$

According to XRD analysis, full conversion from ilmenite to pseudobrookite was not obtained in this work because the sample also contains hematite and iron titanium oxide, $\mathrm{Fe}_{3} \mathrm{Ti}_{3} \mathrm{O}_{10}$. Iron-titanium oxide has a lower oxidation level of iron compared to pseudobrookite which indicates that the oxidation time was too short to reach full oxygen carrier capacity. The mass gain from the oxidation during the pretreatment was $3.2 \mathrm{wt} \%$ which is slightly lower when compared to other studies with the same material from the same origin ${ }^{33}$

The heat treatment resulted in the sintering and adhering of the particles to the ceramic crucible used. These agglomerates were strong and hard to disintegrate. These tendencies during heat treatment of ilmenite have also been observed in earlier studies with ilmenite. ${ }^{39}$ Earlier studies and SEM/EDS analyses suggest that it is the formation of the iron layer, hematite, around the particles that lead to the sintering of the particles. ${ }^{40}$ This 
Table 2. Thermodynamic Equilibrium Calculations of the Phases Found after Reduction or Oxidation ${ }^{a}$

\begin{tabular}{|c|c|c|c|c|}
\hline & & reducing with $\mathrm{CO}$ & reducing with $\mathrm{H}_{2}$ & oxidizing \\
\hline no salt & $\begin{array}{l}\text { no steam } \\
\text { steam }\end{array}$ & $\begin{array}{l}\mathrm{FeOTiO}_{2}, \mathrm{Fe} \\
\mathrm{FeOTiO}_{2},(\mathrm{FeO})_{2} \mathrm{TiO}_{2}\end{array}$ & $\begin{array}{l}\mathrm{FeOTiO}_{2}, \mathrm{Fe} \\
\mathrm{FeOTiO}_{2},(\mathrm{FeO})_{2} \mathrm{TiO}_{2}\end{array}$ & $\begin{array}{l}\mathrm{TiO}_{2}, \mathrm{Fe}_{2} \mathrm{O}_{3} \\
\mathrm{TiO}_{2}, \mathrm{Fe}_{2} \mathrm{O}_{3}\end{array}$ \\
\hline $\mathrm{K}_{2} \mathrm{CO}_{3}$ & $\begin{array}{l}\text { no steam } \\
\text { steam }\end{array}$ & $\begin{array}{l}\mathrm{Fe}, \mathrm{FeOTiO} \\
2, \mathrm{~K}_{2} \mathrm{Ti}_{3} \mathrm{O}_{7},(\mathrm{FeO})_{2} \mathrm{TiO}_{2} \\
(\mathrm{FeO})_{2} \mathrm{TiO}_{2}, \mathrm{~K}_{2} \mathrm{TiO}_{3} \mathrm{O}_{7}, \mathrm{KOH}, \mathrm{K}_{8} \mathrm{Ti}_{5} \mathrm{O}_{14}\end{array}$ & $\begin{array}{l}\mathrm{Fe}, \mathrm{FeOTiO} \\
2, \mathrm{~K}_{2} \mathrm{Ti}_{3} \mathrm{O}_{7} \\
(\mathrm{FeO})_{2} \mathrm{TiO}_{2}, \mathrm{~K}_{2} \mathrm{TiO}_{3} \mathrm{O}_{7}, \mathrm{KOH}, \mathrm{K}_{8} \mathrm{Ti}_{5} \mathrm{O}_{14}\end{array}$ & $\begin{array}{l}\mathrm{Fe}_{2} \mathrm{O}_{3}, \mathrm{~K}_{2} \mathrm{Ti}_{6} \mathrm{O}_{13}, \mathrm{~K}_{2} \mathrm{Ti}_{3} \mathrm{O}_{7} \\
\mathrm{Fe}_{2} \mathrm{O}_{3}, \mathrm{~K}_{2} \mathrm{Ti}_{6} \mathrm{O}_{13}, \mathrm{~K}_{2} \mathrm{Ti}_{3} \mathrm{O}_{7}, \mathrm{KOH}\end{array}$ \\
\hline $\mathrm{KCl}$ & $\begin{array}{l}\text { no steam } \\
\text { steam }\end{array}$ & $\begin{array}{l}\mathrm{FeOTiO}_{2}, \mathrm{Fe}, \mathbf{K C l} \\
\mathrm{FeOTiO}_{2},(\mathrm{FeO})_{2} \mathrm{TiO}_{2}, \mathbf{K C l}, \mathbf{H C l}, \mathbf{K O H}\end{array}$ & $\begin{array}{l}\mathrm{FeOTiO}_{2}, \mathrm{Fe}, \mathrm{TiO}_{2}, \mathrm{KCl} \\
\mathrm{FeOTiO}_{2},(\mathrm{FeO})_{2} \mathrm{TiO}_{2}, \mathbf{K C l}, \mathbf{H C l}, \mathbf{K O H}\end{array}$ & $\begin{array}{l}\mathrm{TiO}_{2}, \mathrm{Fe}_{2} \mathrm{O}_{3}, \mathrm{KCl}, \mathrm{K}_{2} \mathrm{Ti}_{6} \mathrm{O}_{13} \\
\mathrm{TiO}_{2}, \mathrm{Fe}_{2} \mathrm{O}_{3}, \mathrm{KCl}, \mathbf{H C l}, \mathbf{K O H} \\
\mathrm{K}_{2} \mathrm{Ti}_{6} \mathrm{O}_{13}\end{array}$ \\
\hline $\mathrm{K}_{2} \mathrm{SO}_{4}$ & $\begin{array}{l}\text { no steam } \\
\text { steam }\end{array}$ & $\begin{array}{l}\mathrm{FeS}, \mathrm{K}_{2} \mathrm{~S}, \mathrm{~K}_{4} \mathrm{TiO}_{4}, \mathrm{~K}_{8} \mathrm{Ti}_{5} \mathrm{O}_{14} \\
\mathrm{~K}_{2} \mathrm{SO}_{4},(\mathrm{FeO})_{2} \mathrm{TiO}_{2}, \mathrm{~K}_{2} \mathrm{TiO}_{4}, \mathrm{~K}_{8} \mathrm{Ti}_{5} \mathrm{O}_{14}, \mathrm{H}_{2} \mathrm{~S}, \mathrm{KOH}, \\
\quad \mathrm{SO}_{2}\end{array}$ & $\begin{array}{l}\mathrm{FeS}, \mathrm{K}_{4} \mathrm{TiO}_{4}, \mathrm{~K}_{8} \mathrm{Ti}_{5} \mathrm{O}_{14}, \mathrm{~K}_{2} \mathrm{~S} \\
\mathrm{~K}_{2} \mathrm{SO}_{4},(\mathrm{FeO})_{2} \mathrm{TiO}_{2}, \mathrm{~K}_{2} \mathrm{TiO}_{4}, \mathrm{~K}_{8} \mathrm{Ti}_{5} \mathrm{O}_{14}, \mathrm{H}_{2} \mathrm{~S}, \\
\quad \text { KOH }\end{array}$ & $\begin{array}{l}\mathrm{K}_{2} \mathrm{SO}_{4}, \mathrm{TiO}_{2}, \mathrm{Fe}_{2} \mathrm{O}_{3}, \mathrm{~K}_{2} \mathrm{Ti}_{6} \mathrm{O}_{13} \\
\mathrm{~K}_{2} \mathrm{SO}_{4}, \mathrm{TiO}_{2}, \mathrm{Fe}_{2} \mathrm{O}_{3}\end{array}$ \\
\hline $\mathrm{KH}_{2} \mathrm{PO}_{4}$ & $\begin{array}{l}\text { no steam } \\
\text { steam }\end{array}$ & $\begin{array}{l}\mathrm{FeOTiO}_{2}, \mathrm{Fe}, \mathrm{K}_{2} \mathrm{HPO}_{4} \\
\mathrm{FeOTiO}_{2}, \mathrm{~K}_{2} \mathrm{HPO}_{4}, \mathrm{Fe}_{10} \mathrm{P}_{6} \mathrm{O}_{26},(\mathrm{FeO})_{2} \mathrm{TiO}_{2}, \mathbf{K O H}\end{array}$ & $\begin{array}{l}\mathrm{FeOTiO}_{2}, \mathrm{Fe}, \mathrm{K}_{2} \mathrm{HPO}_{4} \\
\mathrm{FeOTiO}_{2}, \mathrm{~K}_{2} \mathrm{HPO}_{4}, \mathrm{Fe}_{10} \mathrm{P}_{6} \mathrm{O}_{26},(\mathrm{FeO})_{2} \mathrm{TiO}_{2} \\
\quad \text { KOH }\end{array}$ & $\begin{array}{l}\mathrm{TiO}_{2}, \mathrm{Fe}_{2} \mathrm{O}_{3}, \mathrm{~K}_{2} \mathrm{HPO}_{4}, \mathrm{Fe}_{6} \mathrm{P}_{2} \mathrm{O}_{14} \\
\mathrm{TiO}_{2}, \mathrm{Fe}_{2} \mathrm{O}_{3}, \mathrm{~K}_{2} \mathrm{HPO}_{4}, \mathrm{Fe}_{6} \mathrm{P}_{2} \mathrm{O}_{14}\end{array}$ \\
\hline
\end{tabular}

${ }^{a}$ Conditions used: 1 bar, $850{ }^{\circ} \mathrm{C}, 1 \mathrm{~g}$ equimolar Ti-Fe ilmenite sample, $4 \%$ potassium in salt samples, 1 mol gas with either $5 \% \mathrm{CO}$ or $\mathrm{H}_{2}$ in $\mathrm{N}_{2}$ for reduction or $20 \% \mathrm{O}_{2}$ in $\mathrm{N}_{2}$ during oxidation. For steam calculations, $50 \%$ of the total gas composition was $\mathrm{H}_{2} \mathrm{O}$ instead of $\mathrm{N}_{2}$. $\mathrm{KOH}$ is in the gas phase. Bold phases are in the gas phase.

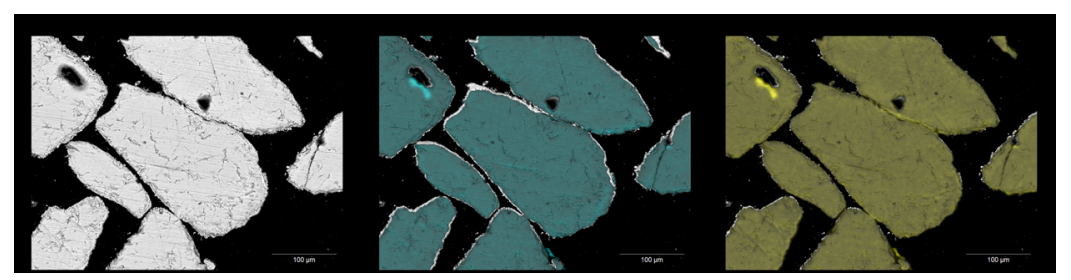

Figure 5. Back-scattered SEM images of cross sections of heat-treated ilmenite $\left(950^{\circ} \mathrm{C}\right)$. The X-ray maps show the sample taken from heat-treated particles at $950^{\circ} \mathrm{C}$ during $6 \mathrm{~h}$. A Fe rich layer has formed on the surface of the ilmenite particle. $\mathrm{Ti}=$ turquoise; $\mathrm{Fe}=$ yellow.

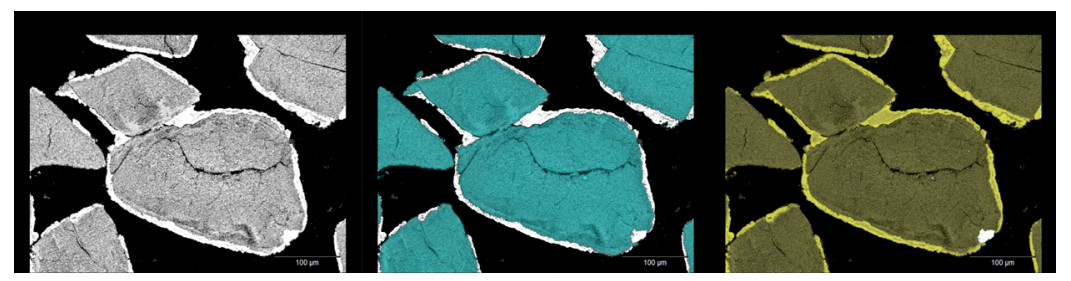

Figure 6. Back-scattered SEM images of cross-sectioned ilmenite reduced, oxidized, and reduced in a TGA in dry $\mathrm{H}_{2}$. The X-ray maps show the thick Fe-rich layer. $\mathrm{Ti}$ = turquoise; $\mathrm{Fe}=$ yellow.

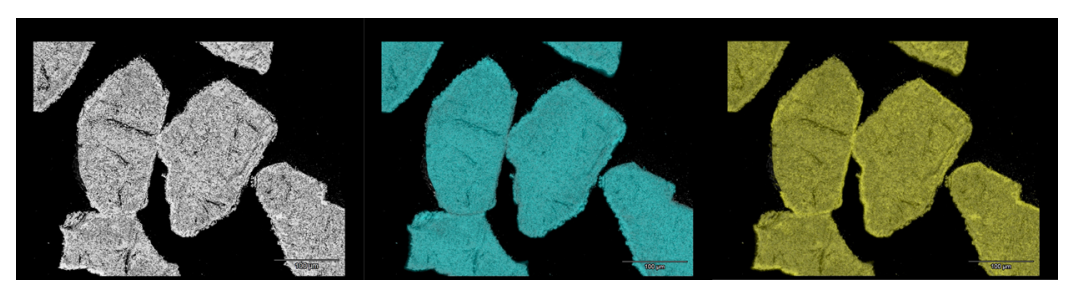

Figure 7. Back-scattered SEM images of cross-sectioned ilmenite reduced, oxidized, and reduced in a TGA in moist $\mathrm{H}_{2}$. The $\mathrm{X}$-ray maps show a thin Fe-rich layer. $\mathrm{Ti}=$ turquoise; $\mathrm{Fe}=$ yellow .

agglomeration occurs during the first heat-up but does not reappear during the following reduction-oxidation cycles although the iron layer remained.

3.2.5. Reduction Cycles of Pure IImenite. A Fe-rich layer was found on top of ilmenite particles in samples taken after the tubular furnace tests (once reduced). After TGA experiments (reduced-oxidized-reduced), this layer was clearly seen when a dry $\mathrm{H}_{2}$ atmosphere was used; see Figure 6. A thin layer was also found on ilmenite using $\mathrm{H}_{2}$ in a moist atmosphere; see Figure 7. The Fe-rich layer was not as pronounced in the other runs using moisture or CO. The ilmenite particles treated in $\mathrm{CO}$ and dry conditions both in TGA and the tubular furnace seemed very porous compared to the other samples analyzed (Figures S1S3).

3.2.6. Reduction Cycles of IImenite $-\mathrm{K}_{2} \mathrm{CO}_{3}$ Mixtures. SEM analyses showed that potassium penetrated the ilmenite particle forming K-titanates. The penetration was most pronounced after the TGA experiments using a dry $\mathrm{H}_{2}$ atmosphere. Iron may have migrated outward to the surface leaving space for potassium to migrate inward and react; see Figure 8 . When moisture was present, $\mathrm{K}_{2} \mathrm{CO}_{3}$ may have reacted forming also other compounds such as $\mathrm{KOH}$ and potassium may even have evaporated from the sample. Evaporation can be expected from 


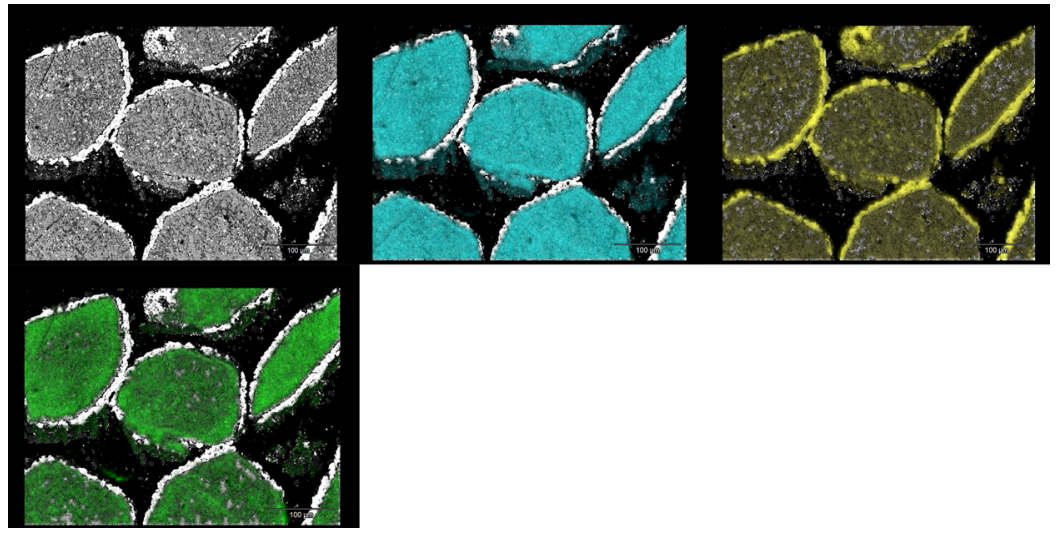

Figure 8. Back-scattered SEM images of cross sections of an ilmenite- $\mathrm{K}_{2} \mathrm{CO}_{3}$ mixture reduced, oxidized, and reduced in a TGA in dry $\mathrm{H}_{2}$. The $\mathrm{X}$-ray maps show the thick $\mathrm{Fe}$-rich layer. $\mathrm{Ti}=$ turquoise; $\mathrm{Fe}=$ yellow; $\mathrm{K}=$ green.

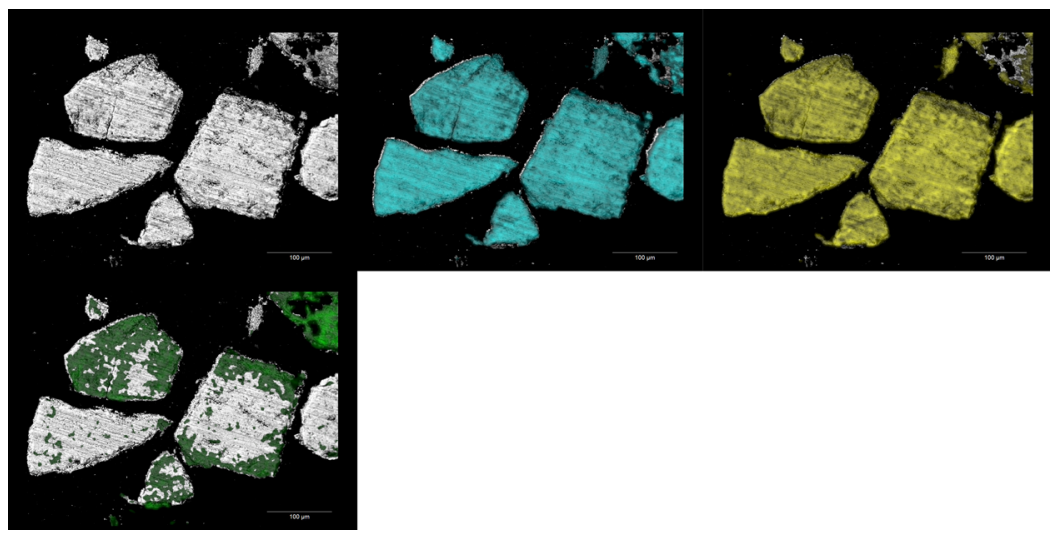

Figure 9. Back-scattered SEM images of cross sections of an ilmenite- $\mathrm{K}_{2} \mathrm{CO}_{3}$ mixture reduced, oxidized, and reduced in a TGA in moist $\mathrm{H}_{2}$. The $\mathrm{X}$-ray maps show some penetration of $\mathrm{K}$ into the ilmenite particles. $\mathrm{Ti}=$ turquoise; $\mathrm{Fe}=$ yellow; $\mathrm{K}=$ green.

the lower amount of potassium observed in the samples; compare Figures 9 with 8 .

In a dry $\mathrm{CO}$ atmosphere, potassium penetrated far less into the particles. Probably, CO cannot penetrate the pores or diffuse through the ilmenite particles as well as $\mathrm{H}_{2}$. This is seen in less segregation of iron to the surface and smaller penetration of potassium. In a moist atmosphere, the water-gas-shift reaction taking place may have led to the formation of $\mathrm{H}_{2}$. The presence of $\mathrm{H}_{2}$ led to higher penetration of $\mathrm{K}$ into the particles compared to $\mathrm{CO}$.

The results from the tubular tests were comparable with the TGA results. A moist atmosphere seemed to facilitate the formation of volatile $\mathrm{KOH}$. Thus, less penetration was seen after reduction using moist $\mathrm{CO}$.

When conducting alkaline roasting of ilmenite, $\mathrm{NaOH}$ is the most common additive to obtain an increased separation of $\mathrm{Fe}$ and Ti. $\mathrm{K}_{2} \mathrm{CO}_{3}$ is also commonly used and has the same effects. ${ }^{25}$ There was, therefore, no surprise that the samples containing this ash component showed greater segregation between iron and titanium when compared to pure ilmenite. The presence of potassium increased the frequency of nucleation sports where iron has segregated. Similar findings have been seen in rutile production from ilmenite. ${ }^{23}$

Figure 10 summarizes the possible reactions that may take place when $\mathrm{K}_{2} \mathrm{CO}_{3}$ is present in CLC. This scheme is based on the experimental findings from XRD, SEM/EDS, TGA, and thermodynamic calculations in FactSage 7.0; see Table 2. It should be noted that unstable $\mathrm{K}_{2} \mathrm{O}$ directly forms K-titanates. In

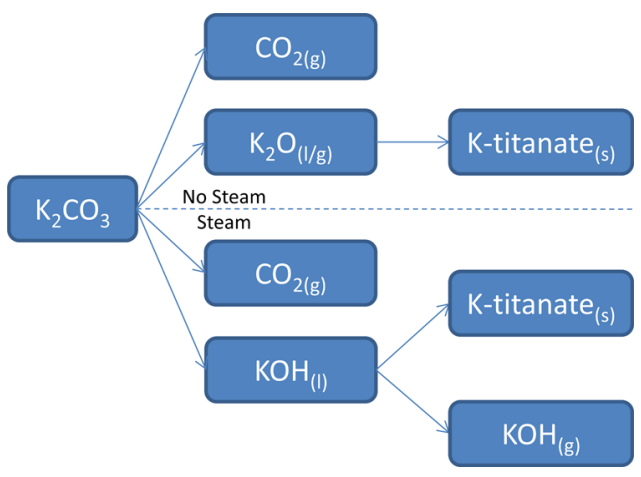

Figure 10. Suggested reactions for reduction of ilmenite- $\mathrm{K}_{2} \mathrm{CO}_{3}$ mixtures in a dry or wet reducing atmosphere at $850^{\circ} \mathrm{C}$.

the presence of steam, $\mathrm{KOH}$ may form. The formed $\mathrm{KOH}$ may either evaporate or react with the ilmenite to form K-titanates. K-titanate formation results in the formation of iron oxides that are more reactive than ilmenite resulting in an increased reaction rate with $\mathrm{CO} .^{33}$

No quantification of potassium was performed on the samples after exposure or on gases out from the tubular furnace or the TGA. In the future, such gas analyses could shed more light on the differences found between the two test setups.

3.2.7. Reduction Cycles of Ilmenite $-\mathrm{K}_{2} \mathrm{SO}_{4}$ Mixtures. All the ilmenite $-\mathrm{K}_{2} \mathrm{SO}_{4}$ mixtures treated in dry atmospheres showed similar results and were comparable to the findings of 


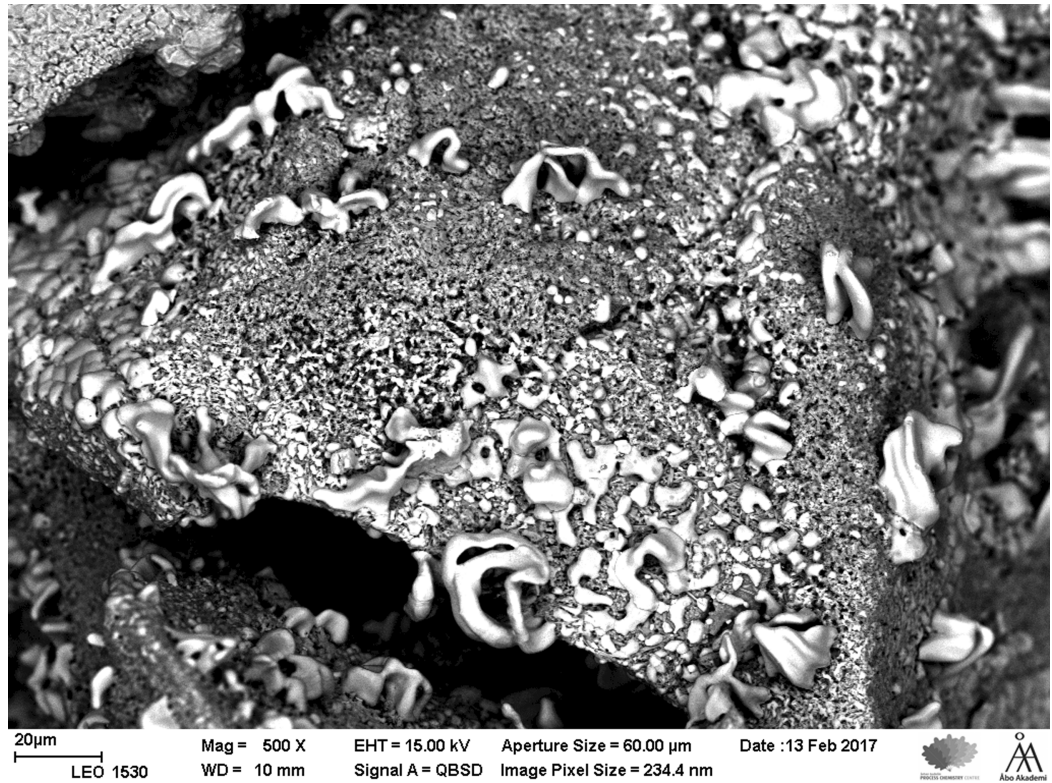

Figure 11. Secondary electron SEM image of the surface of an ilmenite- $\mathrm{K}_{2} \mathrm{SO}_{4}$ mixture reduced in the tubular furnace under dry $\mathrm{CO}$ atmosphere. The figure shows the particle surface in gray and the elementary iron structures in white that were formed during the reduction.

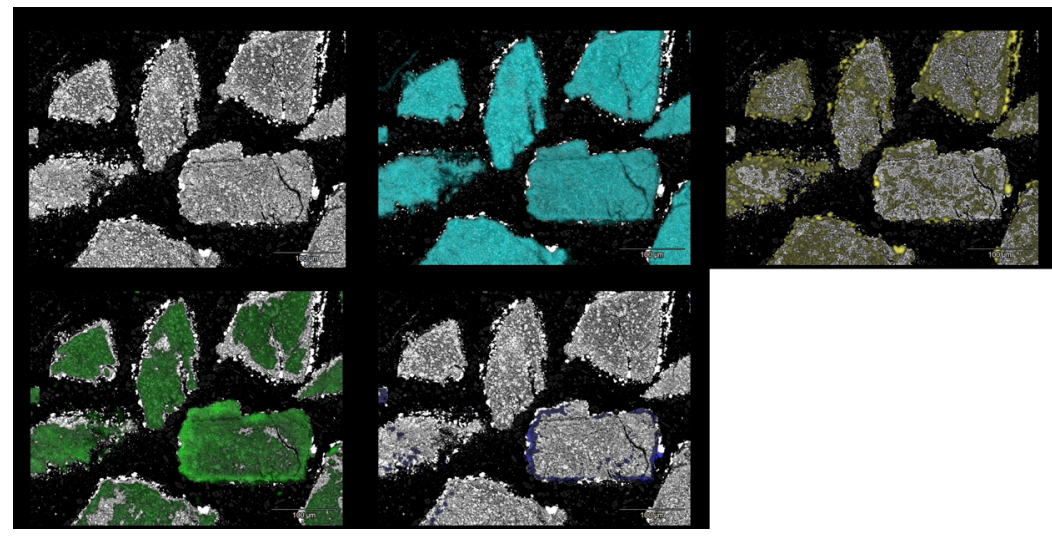

Figure 12. Back-scattered SEM images of cross sections of an ilmenite- $\mathrm{K}_{2} \mathrm{SO}_{4}$ mixture reduced, oxidized, and reduced in a TGA in dry $\mathrm{H}_{2}$. The $\mathrm{X}$-ray maps show the thick Fe-rich layer. $\mathrm{Ti}=$ turquoise; $\mathrm{Fe}=$ yellow; $\mathrm{K}=$ green, $\mathrm{S}=$ blue.

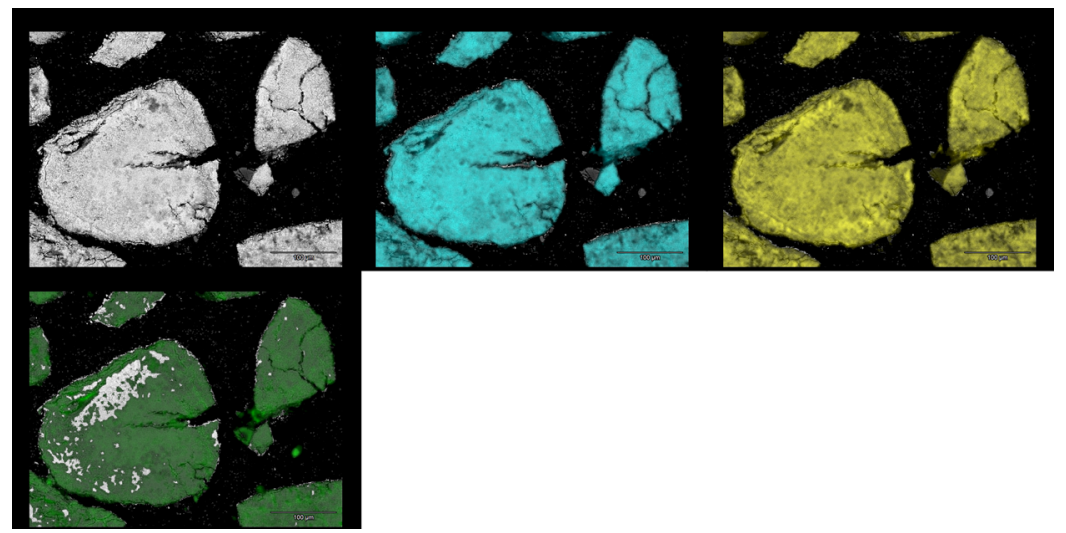

Figure 13. Back-scattered SEM images of cross sections of an ilmenite- $\mathrm{K}_{2} \mathrm{SO}_{4}$ mixture reduced, oxidized, and reduced in a $\mathrm{TGA}$ in moist $\mathrm{H}_{2}$. Ti $=$ turquoise; $\mathrm{Fe}$ = yellow; $\mathrm{K}=$ green, no sulfur could be detected with $\mathrm{SEM} / \mathrm{EDS}$ analyses.

Zevenhoven et al. ${ }^{19}$ SEM analyses showed that iron diffused toward the surface of the sample. On samples reduced once in the tubular furnace, elementary iron formed large structures on the surface of the particles. These iron structures can be seen in
Figure 11. This feature may originate from the $\mathrm{K}_{2} \mathrm{SO}_{4}$ that reacted with $\mathrm{Fe}$ and formed $\mathrm{FeS}$ on the surface of the particles. The effect of the addition of sulfur is well known from the socalled Becher process where sulfur addition during alkali 
roasting improves the synthetic rutile production. In the reduction step in this process, $\mathrm{FeS} \cdot \mathrm{TiO}_{2}$ are formed that are favorable for the following separation steps to maintain pure rutile. $^{27,41}$ The samples taken after the CLC cycles showed that $\mathrm{K}$ penetrated the particles to a greater extent when compared to the ilmenite $-\mathrm{K}_{2} \mathrm{CO}_{3}$ samples. Only some $\mathrm{K}_{2} \mathrm{SO}_{4}$ could be found on the surface.

Also, ilmenite $-\mathrm{K}_{2} \mathrm{SO}_{4}$ mixtures treated with steam in either $\mathrm{CO}$ or $\mathrm{H}_{2}$ showed similar results as the ilmenite $-\mathrm{K}_{2} \mathrm{CO}_{3}$ mixtures. As with $\mathrm{K}_{2} \mathrm{CO}_{3}$, the sample showed some increased tendencies for the segregation of iron to the surface and formation of potassium titanite compared to the control sample.

In conditions with steam, no sulfur could be detected with SEM/EDS. Indicated from the weight loss and thermodynamic calculation, $\mathrm{H}_{2} \mathrm{~S}$ and $\mathrm{SO}_{2}$ might have been formed as gases emitting from the experiment; see Table 2. Without steam, sulfur was found and detected with XRD forming FeS on the surface of the particles. Sulfur was detected on the surface of the particles together with iron. Compare Figures 12 with 13 to see the difference in especially iron distribution. The segregation is very clear without steam, while with steam, the iron distribution is still quite even throughout the particle.

A summary based on the experimental findings in XRD, SEM/ EDS, TGA, and thermodynamic calculations of expected reactions of ilmenite $-\mathrm{K}_{2} \mathrm{SO}_{4}$ mixtures is presented in Figure 14.

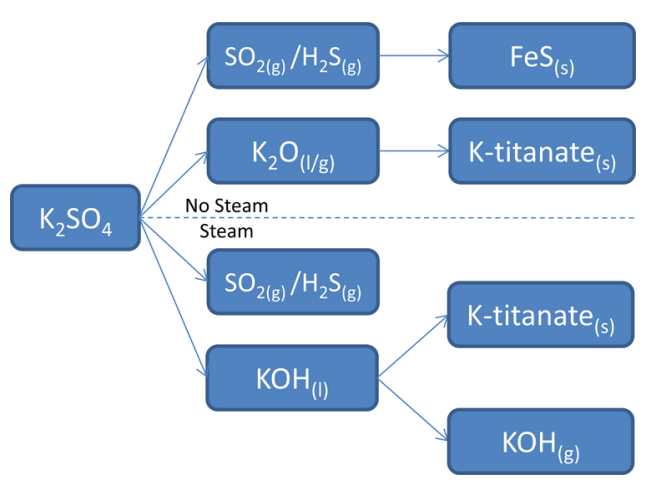

Figure 14. Suggested reactions for reduction of ilmenite $-\mathrm{K}_{2} \mathrm{SO}_{4}$ mixtures in a dry or wet reducing atmosphere at $850{ }^{\circ} \mathrm{C}$. The formation of $\mathrm{SO}_{2}$ or $\mathrm{H}_{2} \mathrm{~S}$ depends on whether the reduction is performed with $\mathrm{CO}$ or $\mathrm{H}_{2}$ and if steam is present.
3.2.8. Reduction Cycles of Ilmenite- $\mathrm{KH}_{2} \mathrm{PO}_{4}$ Mixtures. Exposed to heat, $\mathrm{KH}_{2} \mathrm{PO}_{4}$ decomposed to $\mathrm{KPO}_{3}$ that has a low melting temperature. $\mathrm{KPO}_{3}$ formed a coating around the particles that caused agglomeration and decreased reactivity when $\mathrm{CO}$ was used as reducing gas. The formation of $\mathrm{KPO}_{3}$ could also be seen from XRD, Table 1 . The agglomeration, that occurred for all tests using $\mathrm{KH}_{2} \mathrm{PO}_{4}$, can be described according to the first agglomeration mechanisms. The salt forming a sticky melt causes the particles to agglomerate. ${ }^{6,19,42,43}$ The coatings and how these agglomerates particles stick together can be seen in Figures 15 and 16. In comparison to real ash interaction, phosphorus from bio ash has also been observed to accumulate on the surface of the ilmenite particles used in large scale experiments. $^{44}$

$\mathrm{KPO}_{3}$ is also known to act as a fluxing agent that absorbed iron and impurities such as manganese and aluminum but not titanium. Within the titanium industry, this feature has been used using phosphate to absorb impurities from titanium-rich slags. ${ }^{45}$ The iron absorbed to the flux layer, see Figures 15 and 16 , was assumed to originate mostly from the iron-rich layer around the pretreated particles. This was indicated from the interphase between the original particles and the potassium and phosphorus-rich coating, where a layer of increased titanium concentration was observed.

Possible reactions taking place at the ilmenite surface are presented in Figure 17.

Important to notice here is that other interactions with, for example, calcium that is also present to a large extent in bio ash may be of importance for the phosphate interaction. In a similar study, where the calcium-rich oxygen carrier steel converter slag was investigated with $\mathrm{KH}_{2} \mathrm{PO}_{4}$, it was found that a calcium phosphate phase was formed. This did not to the same extent act as a barrier for $\mathrm{CO}$ interaction with the oxygen carrier and had a higher melting temperature resulting in less agglomeration. ${ }^{35}$

3.2.9. Reduction of Ilmenite-KCl Mixtures. TGA experiments with ilmenite- $\mathrm{KCl}$ mixtures are not available because of experimental constraints. The tubular furnace experiments rendered samples once reduced in either dry or moist CO. From the weight loss after reduction and XRD analysis, it could be concluded that the reaction rate was most likely increased because elementary iron was found in the dry reduction atmosphere. This is also in alignment with previous studies with iron oxides using $\mathrm{KCl}$ to increase the reaction rate. ${ }^{46} \mathrm{No} \mathrm{KCl}$ was detected using XRD, indicating that it was evaporated.

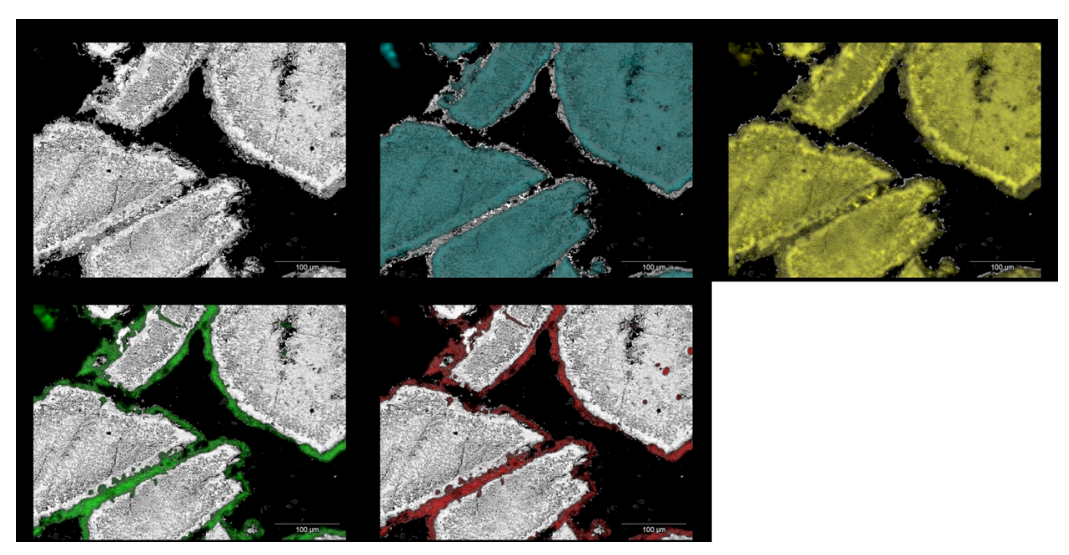

Figure 15. Back-scattered SEM images of cross sections of an ilmenite- $\mathrm{KH}_{2} \mathrm{PO}_{4}$ mixture reduced, oxidized, and reduced in a TGA in dry $\mathrm{H}_{2}$. The $\mathrm{X}$ ray maps show the thick Fe-rich layer and the molten layer in between the particles. $\mathrm{Ti}=$ turquoise; $\mathrm{Fe}=$ yellow; $\mathrm{K}=$ green, $\mathrm{P}=$ red. 


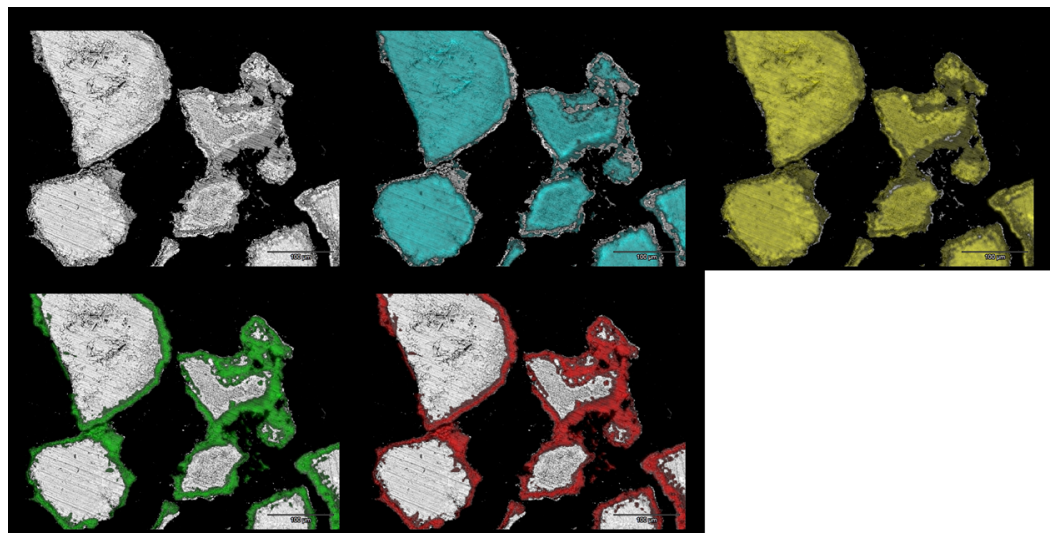

Figure 16. Back-scattered SEM images of cross sections of an ilmenite- $\mathrm{KH}_{2} \mathrm{PO}_{4}$ mixture reduced, oxidized, and reduced in a TGA in moist $\mathrm{H}_{2}$. The $\mathrm{X}$ ray maps show the molten layer in between the particles. $\mathrm{Ti}=$ turquoise; $\mathrm{Fe}=$ yellow; $\mathrm{K}=$ green, $\mathrm{P}=$ red.

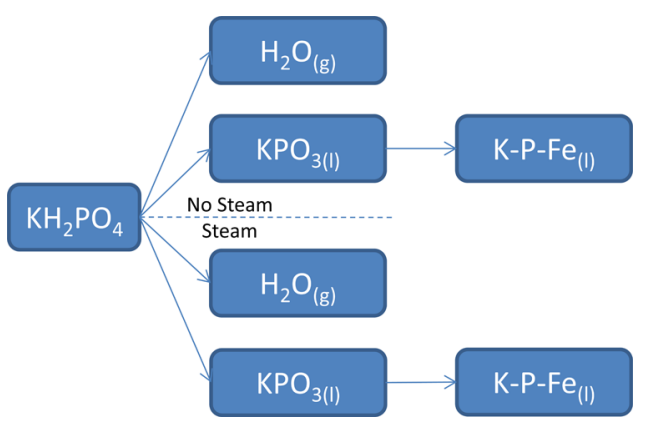

Figure 17. Suggested reactions for reduction of ilmenite- $-\mathrm{KH}_{2} \mathrm{PO}_{4}$ mixtures in dry or wet reducing atmosphere at $850^{\circ} \mathrm{C}$.

SEM analyses from samples taken after dry reduction in $\mathrm{CO}$ show distinct segregation of iron to a few larger nuclei similar to that of the reduced pure ilmenite. The iron was distributed mostly toward the surface of the particles. Only small amounts of potassium but no chloride was detected. Under dry conditions, most $\mathrm{KCl}$ had evaporated from the sample after one reduction cycle.

Ilmenite- $\mathrm{KCl}$ mixtures reduced in moist $\mathrm{CO}$ showed a larger absorption of $\mathrm{K}$ into the sample. Phase analyses showed that $\mathrm{K}$ and $\mathrm{Ti}$ existed in the same spots, indicating the formation of $\mathrm{K}$ titanate. This was confirmed by XRD analyses. Because no $\mathrm{Cl}$ was detected, it is assumed that steam interacted with potassium chloride and formed $\mathrm{HCl}$ and $\mathrm{KOH}$. $\mathrm{KOH}$ in turn partly evaporated and partly reacted with the ilmenite to form Ktitanates. The formation of $\mathrm{HCl}$ and $\mathrm{KOH}$ was also indicated from the thermodynamic calculations; see Table 2.

Based on the experimental findings, XRD, SEM/EDS, TGA, and thermodynamic calculations, the suggested reactions for ilmenite $-\mathrm{KCl}$ mixtures under reducing conditions are summarized in Figure 18.

\section{CONCLUSIONS}

Ash from biomass may cause defluidization of the fluidized bed boilers because of alkali salts in the biomass interacting with the bed material. Ilmenite has been considered to be a bed material with oxygen carrier properties that also is extra resistant toward agglomeration caused by potassium salts. However, previous studies have not considered reducing conditions and the effect of steam under CLC operation on the interaction of the oxygen carrier and alkali salts. This study examined the interaction of potassium salts present in bio ash, with ilmenite under CLC

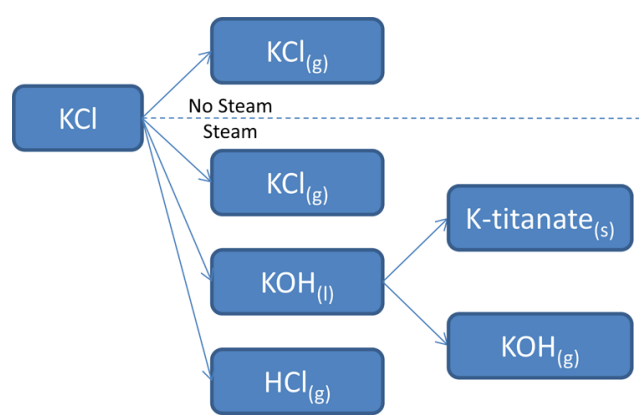

Figure 18. Suggested reactions for reduction of ilmenite- $\mathrm{KCl}$ mixtures in dry or wet reducing atmosphere at $850^{\circ} \mathrm{C}$.

(reduction-oxidation-reduction) conditions at temperatures relevant for the conversion of biomass both in the presence and absence of steam.

It was found that the anions in the potassium salts significantly affected the reactivity and the faith of the salt components. It was observed that the presence of moisture is an important factor affecting the reactive features of the different potassium salts together with ilmenite. In the presence of steam, it was expected that $\mathrm{KOH}$ was formed and evaporated resulting in that less potassium was found to interact with ilmenite.

$\mathrm{K}_{2} \mathrm{CO}_{3}$ and $\mathrm{K}_{2} \mathrm{SO}_{4}$ decreased the oxidation and reduction time of ilmenite. Potassium was absorbed to a significant extent to form K-titanates from $\mathrm{K}_{2} \mathrm{CO}_{3}$ and $\mathrm{K}_{2} \mathrm{SO}_{4}$. $\mathrm{KCl}$ evaporates, and only a minor part of the potassium is absorbed in the presence of steam at $850^{\circ} \mathrm{C}$. None of these three potassium salts did contribute to an increased tendency for agglomeration.

$\mathrm{KH}_{2} \mathrm{PO}_{4}$ increased the tendency to agglomeration. $\mathrm{KH}_{2} \mathrm{PO}_{4}$ formed $\mathrm{KPO}_{3}$, which created a dense coating causing agglomeration and acted as a fluxing agent that adsorbed iron. This coating also acted as a barrier resulting in limited oxygen transport when $\mathrm{CO}$ was used.

Because no other elements commonly present in ash were studied, such as $\mathrm{Ca}$ and $\mathrm{Si}$, other types of interaction with ilmenite should be considered in future studies. The presence of $\mathrm{Ca}$ may change the interaction of $\mathrm{KH}_{2} \mathrm{PO}_{4}$ with ilmenite significantly.

\section{ASSOCIATED CONTENT}

Supporting Information

The Supporting Information is available free of charge at https://pubs.acs.org/doi/10.1021/acsomega.0c02538. 
SEM/EDS of tubular furnace samples, SEM/EDS of TGA experiments with $\mathrm{CO}$, and TGA plot of data from heat-up in dry condition (PDF)

\section{AUTHOR INFORMATION}

\section{Corresponding Author}

Fredrik Hildor - Chemistry and Chemical Engineering, Chalmers University of Technology, 41293 Göteborg, Sweden; ○ orcid.org/0000-0001-7501-4130; Email: fredrik.hildor@ chalmers.se

\section{Authors}

Maria Zevenhoven - Faculty of Science and Technology, Åbo Akademi University, 20500 Turku, Finland

Anders Brink - Faculty of Science and Technology, Åbo Akademi University, 20500 Turku, Finland

Leena Hupa - Faculty of Science and Technology, Åbo Akademi University, 20500 Turku, Finland

Henrik Leion - Chemistry and Chemical Engineering, Chalmers University of Technology, 41293 Göteborg, Sweden

Complete contact information is available at:

https://pubs.acs.org/10.1021/acsomega.0c02538

\section{Notes}

The authors declare no competing financial interest.

\section{ACKNOWLEDGMENTS}

This work was financed by Nordic Flagship Project no. 77732 "negative $\mathrm{CO}_{2}$ emissions in the Nordic energy system" (20152019), funded by the Nordic Energy Research as well as VR, Swedish Research Council (2015-04371), The Swedish Energy Agency (43220-1). Thanks to Peter Backman, Linus Silvander, and Jaana Paananen for help with the experimental work.

\section{REFERENCES}

(1) United Nations. Convention on Climate Change: Climate Agreement of Paris, 2015.

(2) Masson-Delmotte, V.; Zhai, P.; Pörtner, H. O.; Roberts, D.; Skea, J.; Shukla, P. R.; Pirani, A.; Moufouma-Okia, W.; Péan, C.; Pidcock, R.; Connors, S.; Matthews, J. B.; Chen, Y.; Zhou, X.; Gomis, M. I.; Lonnoy, E.; Maycock, T.; Tignor, M.; Waterfield, T. Global Warming of $1.5^{\circ} \mathrm{C}$. An IPCC Special Report on the Impacts of Global Warming of $1.5^{\circ} \mathrm{C}$ above Pre-Industrial Levels and Related Global Greenhouse Gas Emission Pathways, in the Context of Strengthening the Global Response to the Threat of Climate Change, Sustainable Development, and Efforts to Eradicate Poverty; IPCC, 2018.

(3) IPCC. Climate Change 2014: Synthesis Report. Contribution of Working Groups I, II and III to the Fifth Assessment Report of the Intergovernmental Panel on Climate Change, Geneva, Switzerland, 2014.

(4) Zevenhoven, M.; Yrjas, P.; Hupa, M. 14 Ash-Forming Matter and Ash-Related Problems. In Handbook of Combustion; Lackner, M., Winter, F., Agarwal, A. K., Eds.; Solid Fuels; Wiley-VCH Verlag GmbH \& Co. KGaA, 2010; Vol. 4, pp 493-531.

(5) Zevenhoven, M.; Yrjas, P.; Skrifvars, B.-J.; Hupa, M. Characterization of Ash-Forming Matter in Various Solid Fuels by Selective Leaching and Its Implications for Fluidized-Bed Combustion. Energy Fuels 2012, 26, 6366-6386.

(6) Elled, A.-L.; AÅmand, L.-E.; Steenari, B.-M. Composition of Agglomerates in Fluidized Bed Reactors for Thermochemical Conversion of Biomass and Waste Fuels: Experimental Data in Comparison with Predictions by a Thermodynamic Equilibrium Model. Fuel 2013, 111, 696-708.

(7) Adánez, J.; De Diego, L. F.; García-Labiano, F.; Gayán, P.; Abad, A.; Palacios, J. M. Selection of Oxygen Carriers for Chemical-Looping Combustion. Energy Fuels 2004, 18, 371-377.
(8) Bhavsar, S.; Najera, M.; Solunke, R.; Veser, G. Chemical Looping: To Combustion and Beyond. Catal. Today 2014, 228, 96-105.

(9) Knutsson, P.; Linderholm, C. Characterization of Ilmenite Used as Oxygen Carrier in a $100 \mathrm{KW}$ Chemical-Looping Combustor for Solid Fuels. Appl. Energy 2015, 157, 368-373.

(10) Lyngfelt, A.; Linderholm, C. Chemical-Looping Combustion of Solid Fuels - Technology Overview and Recent Operational Results in $100 \mathrm{KW}$ Unit. Energy Procedia 2014, 63, 98-112.

(11) Xu, L.; Schwebel, G. L.; Knutsson, P.; Leion, H.; Li, Z.; Cai, N. Performance of Industrial Residues as Low Cost Oxygen Carriers. Energy Procedia 2017, 114, 361-370.

(12) Leion, H.; Mattisson, T.; Lyngfelt, A. Use of Ores and Industrial Products as Oxygen Carriers in Chemical-Looping Combustion. Energy Fuels 2009, 23, 2307-2315.

(13) Hildor, F.; Mattisson, T.; Leion, H.; Linderholm, C.; Rydén, M. Steel Converter Slag as an Oxygen Carrier in a 12 MWth CFB Boiler Ash Interaction and Material Evolution. Int. J. Greenhouse Gas Control 2019, 88, 321-331.

(14) Leion, H.; Lyngfelt, A.; Johansson, M.; Jerndal, E.; Mattisson, T. The Use of Ilmenite as an Oxygen Carrier in Chemical-Looping Combustion. Chem. Eng. Res. Des. 2008, 86, 1017-1026.

(15) Jerndal, E.; Leion, H.; Axelsson, L.; Ekvall, T.; Hedberg, M.; Johansson, K.; Källén, M.; Svensson, R.; Mattisson, T.; Lyngfelt, A. Using Low-Cost Iron-Based Materials as Oxygen Carriers for Chemical Looping Combustion Chemical Looping -An Alternative Concept for Efficient and Clean Use of Fossil Resources La Boucle Chimique -Un Concept Alternatif Pour Un Usage Propre et Efficace Des. Oil Gas Sci. Technol. 2011, 66, 235-248.

(16) Rydén, M.; Moldenhauer, P.; Lindqvist, S.; Mattisson, T.; Lyngfelt, A. Measuring Attrition Resistance of Oxygen Carrier Particles for Chemical Looping Combustion with a Customized Jet Cup. Powder Technol. 2014, 256, 75-86.

(17) Lyngfelt, A.; Leckner, B. 1000 MWth Boiler for ChemicalLooping Combustion of Solid Fuels - Discussion of Design and Costs. Appl. Energy 2015, 157, 475-487.

(18) Corcoran, A.; Marinkovic, J.; Lind, F.; Thunman, H.; Knutsson, P.; Seemann, M. Ash Properties of Ilmenite Used as Bed Material for Combustion of Biomass in a Circulating Fluidized Bed Boiler. Energy Fuels 2014, 28, 7672-7679.

(19) Zevenhoven, M.; Sevonius, C.; Salminen, P.; Lindberg, D.; Brink, A.; Yrjas, P.; Hupa, L. Defluidization of the Oxygen Carrier Ilmenite Laboratory Experiments with Potassium Salts. Energy 2018, 148, 930940.

(20) Thunman, H.; Lind, F.; Breitholtz, C.; Berguerand, N.; Seemann, M. Using an Oxygen-Carrier as Bed Material for Combustion of Biomass in a 12-MWth Circulating Fluidized-Bed Boiler. Fuel 2013, 113, 300-309.

(21) Staničić, I.; Hanning, M.; Deniz, R.; Mattisson, T.; Backman, R.; Leion, H. Interaction of Oxygen Carriers with Common Biomass Ash Components. Fuel Process. Technol. 2020, 200, 106313.

(22) Bao, J.; Li, Z.; Cai, N. Reduction Kinetics of Foreign-IonPromoted Ilmenite Using Carbon Monoxide (CO) for Chemical Looping Combustion. Ind. Eng. Chem. Res. 2013, 52, 10646-10655.

(23) El-Tawil, S. Z.; Morsi, I. M.; Yehia, A.; Francis, A. A. Alkali Reductive Roasting of Ilmenite Ore. Can. Metall. Q. 1996, 35, 31-37.

(24) Foley, E.; MacKinnon, K. P. Alkaline Roasting of Ilmenite. J. Solid State Chem. 1970, 1, 566-575.

(25) Sanchez-Segado, S.; Makanyire, T.; Escudero-Castejon, L.; Hara, Y.; Jha, A. Reclamation of Reactive Metal Oxides from Complex Minerals Using Alkali Roasting and Leaching - an Improved Approach to Process Engineering. Green Chem. 2015, 17, 2059-2080.

(26) Parirenyatwa, S.; Escudero-Castejon, L.; Sanchez-Segado, S.; Hara, Y.; Jha, A. Comparative Study of Alkali Roasting and Leaching of Chromite Ores and Titaniferous Minerals. Hydrometallurgy 2016, 165, 213-226.

(27) Zhang, W.; Zhu, Z.; Cheng, C. Y. A Literature Review of Titanium Metallurgical Processes. Hydrometallurgy 2011, 108, 177188. 
(28) Chen, L.; Bao, J.; Kong, L.; Combs, M.; Nikolic, H. S.; Fan, Z.; Liu, K. Activation of Ilmenite as an Oxygen Carrier for Solid-Fueled Chemical Looping Combustion. Appl. Energy 2017, 197, 40-51.

(29) Bao, J.; Li, Z.; Cai, N. Promoting the Reduction Reactivity of Ilmenite by Introducing Foreign Ions in Chemical Looping Combustion. Ind. Eng. Chem. Res. 2013, 52, 6119-6128.

(30) Gogolev, I.; Linderholm, C.; Gall, D.; Schmitz, M.; Mattisson, T.; Pettersson, J. B. C.; Lyngfelt, A. Chemical-Looping Combustion in a $100 \mathrm{KW}$ Unit Using a Mixture of Synthetic and Natural Oxygen Carriers - Operational Results and Fate of Biomass Fuel Alkali. Int. J. Greenhouse Gas Control 2019, 88, 371-382.

(31) Derda, P.; Zevenhoven, M.; Hupa, M.; Davidsson, K.; AÅmand, L.-E.; Kassman, H.; Zabetta, E. C. Fate of Alkali Metals during CoCombustion of Biodiesel Residues with Coal in a Semi-Industrial CFB Boiler. CFB 2008-Proceedings of the 9th International Conference on Circulating Fluidized Beds, in Conjunction with the 4th International VGB Workshop "Operating Experience with Fluidized Bed Firing Systems", 2008; pp 13-16.

(32) Corcoran, A.; Knutsson, P.; Lind, F.; Thunman, H. Comparing the Structural Development of Sand and Rock Ilmenite during LongTerm Exposure in a Biomass Fired 12 MWth CFB-Boiler. Fuel Process. Technol. 2018, 171, 39-44.

(33) Adánez, J.; Cuadrat, A.; Abad, A.; Gayán, P.; Diego, L. F. D.; García-Labiano, F. Ilmenite Activation during Consecutive Redox Cycles in Chemical-Looping Combustion. Energy Fuels 2010, 24, 1402-1413.

(34) Mattisson, T.; Keller, M.; Linderholm, C.; Moldenhauer, P.; Rydén, M.; Leion, H.; Lyngfelt, A. Chemical-Looping Technologies Using Circulating Fluidized Bed Systems: Status of Development. Fuel Process. Technol. 2018, 172, 1-12.

(35) Störner, F.; Hildor, F.; Leion, H.; Zevenhoven, M.; Hupa, L.; Rydén, M. Potassium Ash Interactions with Oxygen Carriers Steel Converter Slag and Iron Mill Scale in Chemical-Looping Combustion of Biomass - Experimental Evaluation Using Model Compounds. Energy Fuels 2020, 34, 2304-2314.

(36) Bale, C. W.; Bélisle, E.; Chartrand, P.; Decterov, S. A.; Eriksson, G.; Gheribi, A. E.; Hack, K.; Jung, I.-H.; Kang, Y.-B.; Melançon, J.; Pelton, A. D.; Petersen, S.; Robelin, C.; Sangster, J.; Spencer, P.; Van Ende, M.-A. FactSage Thermochemical Software and Databases, 20102016. CALPHAD: Comput. Coupling Phase Diagrams Thermochem. 2016, 54, 35-53.

(37) Gu, H.; Shen, L.; Zhong, Z.; Zhou, Y.; Liu, W.; Niu, X.; Ge, H.; Jiang, S.; Wang, L. Interaction between Biomass Ash and Iron Ore Oxygen Carrier during Chemical Looping Combustion. Chem. Eng. J. 2015, 277, 70-78.

(38) Schwebel, G. L.; Sundqvist, S.; Krumm, W.; Leion, H. Apparent Kinetics Derived from Fluidized Bed Experiments for Norwegian Ilmenite as Oxygen Carrier. J. Environ. Chem. Eng. 2014, 2, 1131-1141. (39) Pröll, T.; Mayer, K.; Bolhàr-Nordenkampf, J.; Kolbitsch, P.; Mattisson, T.; Lyngfelt, A.; Hofbauer, H. Natural Minerals as Oxygen Carriers for Chemical Looping Combustion in a Dual Circulating Fluidized Bed System. Energy Procedia 2009, 1, 27-34.

(40) Zhang, G.; Ostrovski, O. Effect of Preoxidation and Sintering on Properties of Ilmenite Concentrates. Int. J. Miner. Process. 2002, 64, 201-218.

(41) Hiester, N. K. Conversion of Ilmenite to Rutile Utilizing Sulfur Dioxide. U.S. Patent 3,560,153 A, 1971.

(42) Grimm, A.; Skoglund, N.; Boström, D.; Öhman, M. Bed Agglomeration Characteristics in Fluidized Quartz Bed Combustion of Phosphorus-Rich Biomass Fuels. Energy Fuels 2011, 25, 937-947.

(43) Piotrowska, P.; Zevenhoven, M.; Davidsson, K.; Hupa, M.; AÅmand, L.-E.; Barišíc, V.; Coda Zabetta, E. Fate of Alkali Metals and Phosphorus of Rapeseed Cake in Circulating Fluidized Bed Boiler Part 1: Cocombustion with Wood. Energy Fuels 2010, 24, 333-345.

(44) Corcoran, A.; Knutsson, P.; Lind, F.; Thunman, H. Mechanism for Migration and Layer Growth of Biomass Ash on Ilmenite Used for Oxygen Carrier Aided Combustion. Energy Fuels 2018, 32, 8845-8856.
(45) Van Dyk, J. P.; Pistorius, P. C. Evaluation of a Process That Uses Phosphate Additions to Upgrade Titania Slag. Metall. Mater. Trans. B $1999,30,823-829$.

(46) Nakagawa, H.; Ono, Y. Effects of Potassium Chloride on the Reduction of Iron Oxides. Trans. Iron Steel Inst. Jpn. 1985, 25, 10211024. 